\title{
Reference evapotranspiration based on temperature in Minas Gerais state, Brazil
}

\section{Evapotranspiração de referência com base em temperatura no estado de Minas Gerais, Brasil}

\section{Marcus André Braido Pinheiro ${ }^{1 *} \mathbb{D}$, Aline Lílian Marques Oliveira² $\mathbb{D}^{\mathbb{D}}$, João Carlos Ferreira Borges Júnior ${ }^{3} \mathbb{D}$, Evandro Chaves de Oliveira ${ }^{1}$, Luiz Gonsaga de Carvalho ${ }^{4}$}

\author{
'Instituto Federal do Espírito Santo/IFES, Colatina, Espírito Santo, Brasil \\ Universidade Federal de São João del-Rei/UFSJ, Sete Lagoas, MG, Brasil \\ 3Universidade Federal de São João del-Rei/UFSJ, Departamento de Ciências Agrárias, Sete Lagoas, MG, Brasil \\ ${ }^{4}$ Universidade Federal de Lavras/UFLA, Departamento de Engenharia/DEG, Lavras, MG, Brasil \\ ${ }^{*}$ Corresponding author: marcus-andre.b.p@hotmail.com \\ Received in February 15, 2018 and approved in May 27, 2019
}

\begin{abstract}
In the last decades, the areas of irrigated crops in the state of Minas Gerais have grown considerably, contributing to increase agricultural production in the country. Among the techniques of irrigation management, the determination of the water consumption by the plants is based on the reference evapotranspiration (ETO), the objective of this work was to evaluate and calibrate the Hargreaves-Samani (HS) method and a Proposed Method (MP) against the standard Penman-Monteith-FAO method (PM-FAO) for the state of Minas Gerais. For that, data from 52 conventional meteorological stations of the National Institute of Meteorology (INMET) were used. ET, was estimated by the methods cited including the Hargreaves-Samani calibrated method (HScal) based on the mean absolute error (MAE). The analysis of the methods was carried out using the following statistical indicators: root mean square error (RMSE), systematic root mean square error (RMSEs), unsystematic root mean square error (RMSEun), the proportions of systematic and unsystematic mean square error, Willmott's concordance index (d), confidence index (C) and Pearson correlation coefficient ( $r$ ). It was verified that after the calibration, the $\mathrm{HScal}$ method obtained a superior performance to the original HS method in all the studied stations. It was also observed a superior MP performance with respect to the HScal method, in all stations studied.
\end{abstract}

Index Terms: Penman-Monteith-FAO; Water resources management; Hargreaves-Samani; Mean Absolute Error.

\begin{abstract}
RESUMO
Nas últimas décadas, as áreas de cultivos irrigados no estado de Minas Gerais vêm crescendo bastante, contribuindo assim para aumento da produção agrícola no País. Dentre as técnicas de manejo da irrigação, tem-se a determinação do consumo de água pelas plantas tomando por base a evapotranspiração de referência ( $\left.\mathrm{ET}_{0}\right)$, diante disso, objetivou-se com este trabalho, avaliar e calibrar o método HargreavesSamani (HS) e um Método Proposto (MP) frente ao método padrão Penman-Monteith-FAO (PM-FAO) para o estado de Minas Gerais. Para tanto, foram utilizados dados de 52 estações meteorológicas convencionais do Instituto Nacional de Meteorologia (INMET). Estimou-se a ET pelos métodos citados incluindo o método Hargreaves-Samani calibrado (HScal). com base no erro absoluto médio (EAM). A análise dos métodos foi conduzida mediante aos seguintes indicadores estatísticos: raiz quadrada do erro quadrático médio (REQM), raiz quadrada do erro quadrático médio sistemático (REQMs), raiz quadrada do erro quadrático médio não sistemático (REQMns), proporções do erro quadrático médio sistemático e não sistemático, índice de concordância de Willmott (d), índice de confiança (C) e coeficiente de correlação (r). Constatou-se que o após calibração, o método HScal obteve um desempenho superior ao método HS original em todas as estações estudadas. Observou-se também um desempenho superior do MP com relação ao método HScal, em todas as estações estudadas.
\end{abstract}

Termos para Indexação: Penman-Monteith-FAO; Manejo dos recursos hídricos; Hargreaves-Samani; Erro Absoluto Médio.

\section{INTRODUCTION}

Brazil has about 6.95 million hectares (ha) of irrigated area according to data from 2017 of the National Water Agency - ANA. The State of Minas Gerais contributes significantly to the production of grains in Brazil, mainly through irrigated agriculture. Data from the National Water Agency-ANA(ANA, 2017) reported the existence in 2015, in Minas Gerais, of 1082.373 hectares irrigated which are distributed by different forms of irrigation. 
PINHEIRO, M. A. B. et al.

Evapotranspiration is the basis of water management and is commonly the largest and most important component in the water balance in agricultural systems. His knowledge is essential for the design of irrigation projects, establishment of irrigation management and planning in agricultural systems. The importance of evapotranspiration is verified in several studies, not only in the field of Agricultural Sciences, but also in Meteorology, Geography, Hydrology and Ecology.

By definition, the reference evapotranspiration, $\mathrm{ET}_{0}$, is the evapotranspiration rate of a reference surface, covered by a hypothetical crop, with a height of $0.12 \mathrm{~m}$, a surface aerodynamic resistance of $70 \mathrm{~s} \mathrm{~m}^{-1}$ and albedo of 0.23 , with no soil moisture restriction, actively growing and completely covering the soil surface (Allen et al., 1998).

The FAO Penman-Monteith method (FAO-PM) is considered the standard for calculating $\mathrm{ET}_{0}$ (Pereira et al., 2015), since it physically models evapotranspiration. The application of this method requires a set of data, as minimum and maximum air temperature, relative humidity, wind speed, pressure atmospheric, sunshine duration and, or radiation balance. The application of a large database is the main obstacle to the application of the standard method, mainly in climatology studies since it is common the occurrence of failures in historical series of meteorological elements. In this sense, it is observed that meteorological stations to obtain the meteorological data required by the FAO-PM method have, in general, a high financial cost, which prevents a considerable portion of agricultural producers to use this kind of data.

The Hargreaves-Samani (HS) method employs only maximum and minimum air temperature data to estimate $\mathrm{ET}_{0}$ (Hargreaves; Samani, 1985; Paredes et al., 2017; Valiantzas 2013; Valipour, 2015). This empirical method is notable for its wide use and is suggested by Allen et al. (1998) and Pereira et al. (2015) as an alternative to FAO-PM when only air temperature data are available. Due to the empirical nature of this method, there is a need for local calibration against the standard method with a view to gaining accuracy, even using machine learning techniques (Borges Júnior et al., 2017, Shiri et al., 2014, Shiri et al., 2015).

The development of equations for estimation of $\mathrm{ET}_{0}$ with only temperature data can contribute to a better monitoring of the water requirement by the crops and can be used by producers with low purchasing power, since simple meteorological stations are required for data collection. These methods are also options for filling in historical $\mathrm{ET}_{0}$ data failures, such data needed for irrigation project design, planning and risk analysis (Borges Júnior et al., 2008a, 2008b).

This study had the objective to evaluate HS and calibrate HScal methods and a Proposed Method (MP) against the FAO-PM method to estimate the reference evapotranspiration, considering historical series of daily meteorological data from stations in Minas Gerais and some adjacent to this state.

\section{MATERIAL AND METHODS}

\section{Study area}

The study region is composed by the state of Minas Gerais with some adjacent stations to this state (Figure 1).

For this work, we selected 52 conventional weather stations of the National Institute of Meteorology - INMET, Brazil, with series provided by Bank of Meteorological Data for Teaching and Research - BDMEP (Table 1). Due to the proximity, some stations adjacent to the state of Minas Gerais were chosen, favoring a better characterization of the region of the study.

\section{Estimation of reference evapotranspiration $\mathrm{ET}_{0}$}

Daily $\mathrm{ET}_{0}$ calculations were performed using the FAO-PM method, according to Allen et al., 1998.

$\mathrm{ET}_{0 \mathrm{PM}}=\frac{0.408 \Delta\left(\mathrm{R}_{\mathrm{n}}-\mathrm{G}\right)+\gamma \frac{900}{\mathrm{~T}_{\mathrm{med}}+273} \mathrm{u}_{2}\left(\mathrm{e}_{\mathrm{s}}-\mathrm{e}_{\mathrm{a}}\right)}{\Delta+\gamma\left(1+0.34 \mathrm{u}_{2}\right)}$

Where, $\mathrm{ET}_{0_{\mathrm{P}}}$ is the reference evapotranspiration calculated by the FAO-PM method $\left(\mathrm{mm} \mathrm{d}^{-1}\right), \mathrm{R}_{\mathrm{n}}$ is the net radiation at the crop surface $\left(\mathrm{MJ} \mathrm{m}^{-2} \mathrm{~d}^{-1}\right), \mathrm{G}$ is the soil heat flux density $\left(\mathrm{MJ} \mathrm{m}^{-2} \mathrm{~d}^{-1}\right), \mathrm{T}_{\text {med }}$ is the mean daily air temperature at $2 \mathrm{~m}$ height $\left({ }^{\circ} \mathrm{C}\right), \mathrm{u}_{2}$ is the wind speed at $2 \mathrm{~m}$ height $\left(\mathrm{m} \mathrm{s}^{-1}\right), \mathrm{e}_{\mathrm{s}}$ is the saturation vapour pressure $(\mathrm{kPa}), \mathrm{e}_{\mathrm{a}}$ is the actual vapour pressure $(\mathrm{kPa}), \Delta$ is the slope vapour pressure curve $\left(\mathrm{kPa}^{\circ} \mathrm{C}^{-1}\right)$ and $\gamma$ is the psychrometric constant $\left(\mathrm{kPa}^{\circ} \mathrm{C}^{-1}\right)$.

The following equation was used to calculate $\mathrm{ET}_{0}$ by the HS method (Hargreaves e Samani, 1985):

$$
\mathrm{ET}_{0_{\text {нS }}}=\mathrm{A}_{\mathrm{HS}} \mathrm{R}_{\mathrm{a}}\left(\mathrm{T}_{\text {max }}-\mathrm{T}_{\text {min }}\right)^{\mathrm{C}_{\mathrm{HS}}}\left(\mathrm{T}_{\text {med }}+\mathrm{B}_{\mathrm{HS}}\right)
$$

Where, $\mathrm{ET}_{\mathrm{OHS}}$ is the reference evapotranspiration estimated by the HS method $\left(\mathrm{mm} \mathrm{d}^{-1}\right), \mathrm{Ra}$ is the radiation at the "top" of the atmosphere in equivalent evaporation $(\mathrm{mm}$ $\left.\mathrm{d}^{-1}\right), \mathrm{T}_{\max }$ is the maximum air temperature $\left({ }^{\circ} \mathrm{C}\right), \mathrm{T}_{\min }$ is the minimum air temperature $\left({ }^{\circ} \mathrm{C}\right)$ and $\mathrm{A}_{\mathrm{HS}}, \mathrm{B}_{\mathrm{HS}}$ e $\mathrm{C}_{\mathrm{HS}}$ is the parameters of the model, originally equal $0.0023,17.8$ and 0.5 , respectively. 


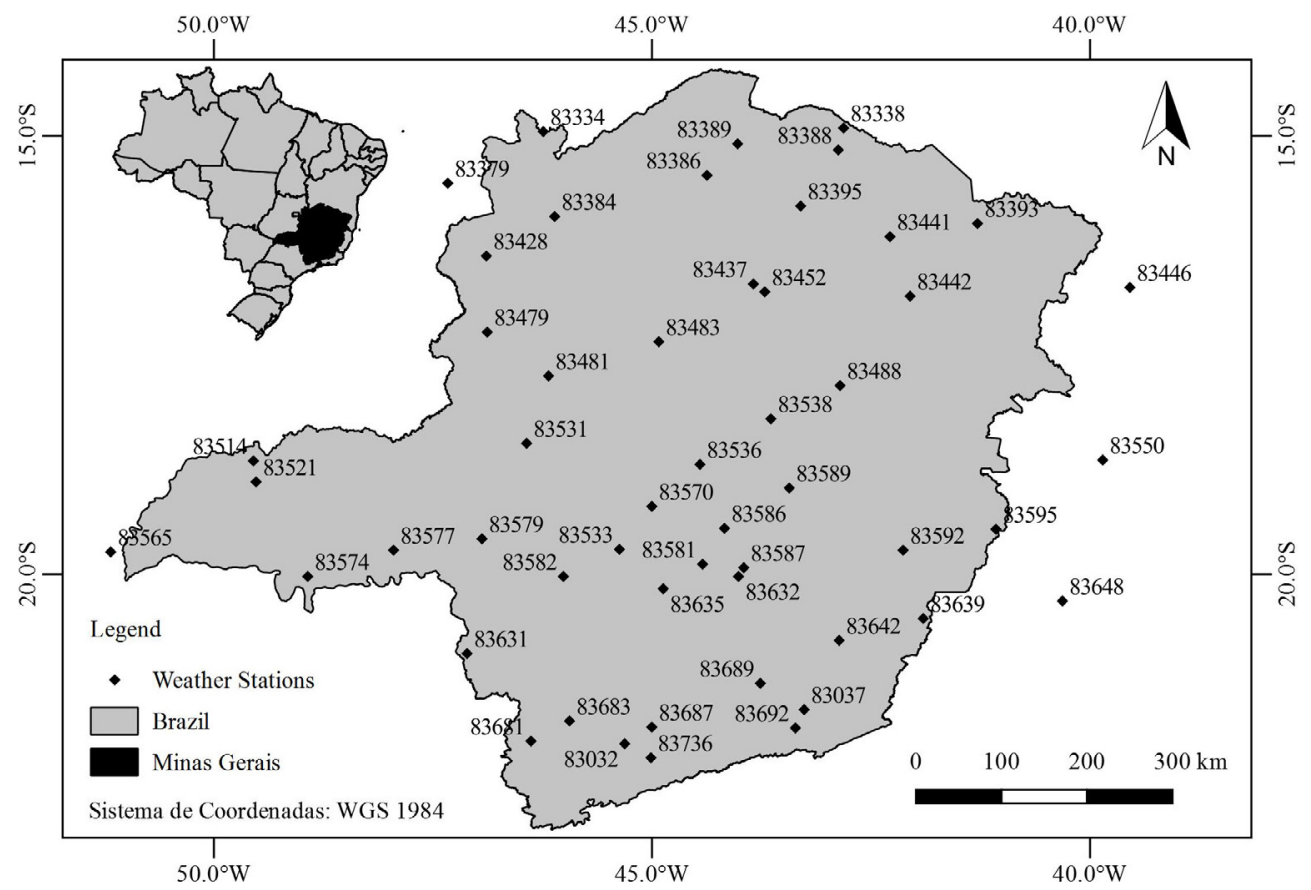

Figure 1: Characterization of the study region.

Table 1: Location of conventional weather stations used.

\begin{tabular}{ccccc}
\hline Station & OMM Code & Latitude & Longitude & Altitude $(\mathrm{m})$ \\
\hline Aimorés - MG & 83595 & $-19.49^{\circ}$ & $-41.07^{\circ}$ & 82.74 \\
Araçuaí - MG & 83442 & $-16.83^{\circ}$ & $-42.05^{\circ}$ & 289.00 \\
Araxá - MG & 83579 & $-19.60^{\circ}$ & $-46.94^{\circ}$ & 1023.61 \\
Arinos - MG & 83384 & $-15.91^{\circ}$ & $-46.10^{\circ}$ & 519.00 \\
Bambuí - MG & 83582 & $-20.03^{\circ}$ & $-46.00^{\circ}$ & 661.27 \\
Barbacena - MG & 83689 & $-21.25^{\circ}$ & $-43.76^{\circ}$ & 1126.00 \\
Belo Horizonte - MG & 83587 & $-19.93^{\circ}$ & $-43.95^{\circ}$ & 915.00 \\
Bom Despacho - MG & 83533 & $-19.71^{\circ}$ & $-45.36^{\circ}$ & 695.00 \\
C. do Mato Dentro - MG & 83589 & $-19.02^{\circ}$ & $-43.43^{\circ}$ & 652.00 \\
Caparaó - MG & 83639 & $-20.51^{\circ}$ & $-41.90^{\circ}$ & 843.18 \\
Capinópolis - MG & 83514 & $-18.71^{\circ}$ & $-49.55^{\circ}$ & 620.60 \\
Caratinga - MG & 83592 & $-19.73^{\circ}$ & $-42.13^{\circ}$ & 609.65 \\
Coronel Pacheco - MG & 83037 & $-21.55^{\circ}$ & $-43.26^{\circ}$ & 435.00 \\
Curvelo - MG & 83536 & $-18.74^{\circ}$ & $-44.45^{\circ}$ & 672.00 \\
Diamantina - MG & 83538 & $-18.23^{\circ}$ & $-43.64^{\circ}$ & 1296.12 \\
Divinópolis - MG & 83635 & $-20.17^{\circ}$ & $-44.87^{\circ}$ & 788.35 \\
Espinosa - MG & 83338 & $-14.91^{\circ}$ & $-42.80^{\circ}$ & 569.64 \\
Florestal - MG & 83581 & $-19.88^{\circ}$ & $-44.41^{\circ}$ & 760.00 \\
\hline
\end{tabular}

Continue... 
Table 1: Continuation.

\begin{tabular}{|c|c|c|c|c|}
\hline Station & OMM Code & Latitude & Longitude & Altitude $(\mathrm{m})$ \\
\hline Formosa - GO & 83379 & $-15.54^{\circ}$ & $-47.33^{\circ}$ & 935.19 \\
\hline Formoso - MG & 83334 & $-14.94^{\circ}$ & $-46.23^{\circ}$ & 840.00 \\
\hline Frutal - MG & 83574 & $-20.03^{\circ}$ & $-48.93^{\circ}$ & 543.67 \\
\hline Guaratinga - BA & 83446 & $-16.73^{\circ}$ & $-39.54^{\circ}$ & 194.67 \\
\hline Ibirité - MG & 83632 & $-20.03^{\circ}$ & $-44.01^{\circ}$ & 814.54 \\
\hline Itamarandiba - MG & 83488 & $-17.85^{\circ}$ & $-42.85^{\circ}$ & 914.00 \\
\hline Ituiutaba - MG & 83521 & $-18.95^{\circ}$ & $-49.52^{\circ}$ & 560.00 \\
\hline Janaúba - MG & 83395 & $-15.80^{\circ}$ & $-43.29^{\circ}$ & 516.00 \\
\hline Januária - MG & 83386 & $-15.44^{\circ}$ & $-44.36^{\circ}$ & 473.71 \\
\hline João Pinheiro - MG & 83481 & $-17.74^{\circ}$ & $-46.17^{\circ}$ & 760.36 \\
\hline Juiz de Fora - MG & 83692 & $-21.76^{\circ}$ & $-43.36^{\circ}$ & 939.96 \\
\hline Juramento - MG & 83452 & $-16.78^{\circ}$ & $-43.71^{\circ}$ & 648.00 \\
\hline Lambari - MG & 83032 & $-21.94^{\circ}$ & $-45.31^{\circ}$ & 878.45 \\
\hline Lavras - MG & 83687 & $-21.75^{\circ}$ & $-45.00^{\circ}$ & 918.84 \\
\hline Machado - MG & 83683 & $-21.68^{\circ}$ & $-45.94^{\circ}$ & 873.35 \\
\hline Mocambinho - MG & 83389 & $-15.08^{\circ}$ & $-44.01^{\circ}$ & 452.00 \\
\hline Monte Azul - MG & 83388 & $-15.16^{\circ}$ & $-42.86^{\circ}$ & 625.00 \\
\hline Montes Claros - MG & 83437 & $-16.68^{\circ}$ & $-43.84^{\circ}$ & 652.00 \\
\hline Paracatu - MG & 83479 & $-17.24^{\circ}$ & $-46.88^{\circ}$ & 712.00 \\
\hline Paranaíba - MS & 83565 & $-19.75^{\circ}$ & $-51.18^{\circ}$ & 331.25 \\
\hline Patos de Minas - MG & 83531 & $-18.51^{\circ}$ & $-46.43^{\circ}$ & 940.28 \\
\hline Pedra Azul - MG & 83393 & $-16.00^{\circ}$ & $-41.28^{\circ}$ & 648.91 \\
\hline Pirapora - MG & 83483 & $-17.34^{\circ}$ & $-44.92^{\circ}$ & 505.24 \\
\hline Poços de Caldas - MG & 83681 & $-21.91^{\circ}$ & $-46.38^{\circ}$ & 1150.00 \\
\hline Pompéu - MG & 83570 & $-19.22^{\circ}$ & $-45.00^{\circ}$ & 690.91 \\
\hline Salinas - MG & 83441 & $-16.15^{\circ}$ & $-42.28^{\circ}$ & 471.32 \\
\hline São Lourenço - MG & 83736 & $-22.10^{\circ}$ & $-45.01^{\circ}$ & 953.20 \\
\hline São Mateus - ES & 83550 & $-18.70^{\circ}$ & $-39.85^{\circ}$ & 25.04 \\
\hline São S. do Paraíso - MG & 83631 & $-20.91^{\circ}$ & $-47.11^{\circ}$ & 820.00 \\
\hline Sete Lagoas - MG & 83586 & $-19.48^{\circ}$ & $-44.17^{\circ}$ & 732.00 \\
\hline Uberaba - MG & 83577 & $-19.73^{\circ}$ & $-47.95^{\circ}$ & 737.00 \\
\hline Unaí - MG & 83428 & $-16.36^{\circ}$ & $-46.88^{\circ}$ & 460.00 \\
\hline Viçosa - MG & 83642 & $-20.76^{\circ}$ & $-42.86^{\circ}$ & 712.20 \\
\hline Vitória - ES & 83648 & $-20.31^{\circ}$ & $-40.31^{\circ}$ & 36.20 \\
\hline
\end{tabular}

Daily data search was performed between 1961 and 2015 , maximum $\left(\mathrm{T}_{\text {max }}{ }^{\circ} \mathrm{C}\right)$ and minimum $\left(\mathrm{T}_{\text {min }^{\prime}}{ }^{\circ} \mathrm{C}\right)$ air temperature, daily sunshine hours $(n, h)$, average daily wind speed at ten meters high $\left(U_{10^{\prime}} \mathrm{m} \mathrm{s}^{-1}\right)$ and relative humidity average of the daily $(U R, \%)$. The mean temperature $\left(\mathrm{T}_{\text {med }^{\prime}}{ }^{\circ} \mathrm{C}\right)$ was calculated from $\mathrm{T}_{\max }$ and $\mathrm{T}_{\min }$. Inconsistencies were previously verified in the series, being excluded when identified, registering the increase in the number of data failures. 
The work also involved the application of a new proposed method (MP), in which air temperature data are used, taking into consideration, in addition to the average temperature, the thermal amplitude and proportionality between the maximum and minimum local temperature. As in the HS method, radiation is also required at the "top" of the atmosphere, whose variation is defined based on the day of the year and latitude. In the conception of method, it was taken as the basis Borges Junior model for calculation of solar radiation, proposed in Steidle Neto et al. (2015), adapting to obtain the $\mathrm{ET}_{0}$, having the following general equation:

$\mathrm{ET}_{0 \mathrm{MP}}=\mathrm{A}_{\mathrm{MP}} \mathrm{T}_{\text {max }} \mathrm{R}_{\mathrm{a}}\left[\mathrm{B}_{\mathrm{MP}}\left(\mathrm{T}_{\max }-\mathrm{T}_{\min }\right)^{3}+\mathrm{C}_{\mathrm{MP}}\left(\frac{\mathrm{T}_{\text {min }}}{\mathrm{T}_{\text {max }}}\right)^{2}+\mathrm{D}_{\mathrm{MP}} \mathrm{T}_{\text {med }}+\mathrm{E}_{\mathrm{MP}}\right]^{2}$

Where, $\mathrm{ET}_{0 \mathrm{MP}}$ is the reference evapotranspiration calculated by the MP method $\left(\mathrm{mm} \mathrm{d}^{-1}\right)$, Ra is the radiation at the "top" of the atmosphere in equivalent evaporation $\left(\mathrm{mm} \mathrm{d}^{-1}\right), \mathrm{T}_{\max }$ is the maximum air temperature $\left({ }^{\circ} \mathrm{C}\right), \mathrm{T}_{\min }$ is the minimum air temperature $\left({ }^{\circ} \mathrm{C}\right)$ and $\mathrm{A}_{\mathrm{MP}}, \mathrm{B}_{\mathrm{MP}}, \mathrm{C}_{\mathrm{MP}}, \mathrm{D}_{\mathrm{MP}}$ e $\mathrm{E}_{\mathrm{MP}}$ is the local model adjustment parameters.

\section{Calibration of methods based on temperature}

The calibration of the parameters of the HS and MP methods was performed to modify the $\mathrm{A}_{\mathrm{HS}}$ and $\mathrm{C}_{\mathrm{HS}}$ coefficients and the $\mathrm{B}_{\mathrm{HS}}$ exponent of the HS method and the $\mathrm{A}_{\mathrm{MP}}, \mathrm{B}_{\mathrm{MP}}, \mathrm{C}_{\mathrm{MP}}, \mathrm{D}_{\mathrm{MP}}$ and $\mathrm{E}_{\mathrm{MP}}$ coefficients of the new MP seeking to minimize the mean absolute error (MAE) (Willmott, et al., 2012). As initial values for the calibration procedure, the original values of the HS method were used and for the MP the coefficients were equal to 0.5 .

This process was performed using the Solver tool of the Microsoft Office Excel ${ }^{\circledR} 2016$ spreadsheet, configuring it for application of the non-linear GRG solution method and convergence of 0.000001 ; in the field "Derivatives" the marker was applied in "Forward" and in the "Multiinitialization" field the "Required Limits in Variables" option was selected.

\section{Test statistics models}

The methods were evaluated based on the mean absolute error (MAE), root mean square error (RMSE), systematic root mean square error (RMSEs), unsystematic root mean square error (RMSEun), the proportions of systematic and unsystematic mean square error, Willmott's concordance index (d), Pearson correlation coefficient (r), besides the means, standard deviations (sd), coefficient of variation $(\mathrm{cv})$ and maximum and minimum.

$$
\begin{aligned}
& \mathrm{MAE}=\mathrm{N}_{\mathrm{o}}^{-1} \sum_{\mathrm{i}=1}^{\mathrm{N}}\left|\mathrm{P}_{\mathrm{i}}-\mathrm{O}_{\mathrm{i}}\right| \\
& \mathrm{RMSE}=\mathrm{MSE}^{0.5}=\left[\mathrm{N}_{\mathrm{o}}^{-1} \sum_{\mathrm{i}=1}^{\mathrm{N}}\left(\mathrm{P}_{\mathrm{i}}-\mathrm{O}_{\mathrm{i}}\right)^{2}\right]^{0.5} \\
& \operatorname{RMSEs}=\mathrm{MSEs}^{0.5}=\left[\mathrm{N}_{\mathrm{o}}^{-1} \sum_{\mathrm{i}=1}^{\mathrm{N}}\left(\hat{\mathrm{P}}_{\mathrm{i}}-\mathrm{O}_{\mathrm{i}}\right)^{2}\right]^{0.5} \\
& \mathrm{RMSEun}=\mathrm{MSEun}^{0.5}=\left[\mathrm{N}_{\mathrm{o}}^{-1} \sum_{\mathrm{i}=1}^{\mathrm{N}}\left(\hat{\mathrm{P}}_{\mathrm{i}}-\mathrm{P}_{\mathrm{i}}\right)^{2}\right]^{0.5} \\
& \mathrm{~d}=1-\left[\frac{\sum_{\mathrm{i}=1}^{\mathrm{N}}\left(\mathrm{P}_{\mathrm{i}}-\mathrm{O}_{\mathrm{i}}\right)^{2}}{\left.\sum_{\mathrm{i}=1}^{\mathrm{N}}\left(\left|\mathrm{P}_{\mathrm{i}}-\mathrm{O}\right|+\left|\mathrm{O}_{\mathrm{i}}-\mathrm{O}\right|\right)^{2}\right]}\right.
\end{aligned}
$$

Where, $\hat{\mathrm{P}}_{\mathrm{i}}$ is the Pi estimator based on the linear regression model $\left(\mathrm{mm} \mathrm{d}^{-1}\right)$, No is the number of observations, $\mathrm{Pi}$ is the estimated values of ET $\left(\mathrm{mm} \mathrm{d}^{-1}\right)$, Oi is the $\mathrm{ET}_{0}$ values calculated by the FAO-PM method $\left(\mathrm{mm} \mathrm{d}^{-1}\right)$ and $\mathrm{O}$ is the mean of the $\mathrm{ET}_{0}$ values obtained by the standard method $\left(\mathrm{mm} \mathrm{d}^{-1}\right)$.

\section{RESULTS AND DISCUSSION}

The coefficients of the HScal and MP equations are listed in Tables 2 and 3. For purposes of precision in the presentation of the results, the coefficients and exponents of the HScal method were rounded to 6, 3 and 4 decimal places for $\mathrm{A}_{\mathrm{HS}}, \mathrm{B}_{\mathrm{HS}}$ and $\mathrm{C}_{\mathrm{HS}}$, respectively; for the MP were rounded to 6 decimal places for all coefficients. With the rounding procedure, the variation in the mean absolute error (MAE) was less than $10^{-5} \mathrm{~mm} \mathrm{~d}^{-1}$.

The $A_{\mathrm{HS}}$ coefficient values ranged from 0.00067 to 0.004116; the $\mathrm{B}_{\mathrm{HS}}$ and $\mathrm{C}_{\mathrm{HS}}$ coefficients ranged from -6.546 to 36.812 and from 0.3431 to 0.8061 , respectively.

Feng et al. (2017), studying the calibration of the HS model to estimate $\mathrm{ET}_{0}$ for the basin of Sichuan in southwest China through the Bayesian theory, using 19 weather stations from 1961 to 2014, found the coefficient values ranging from 0.00213 to $0.00218,16.19$ to 16.58 , and 0.40 to 0.46 for $\mathrm{A}_{\mathrm{HS}}, \mathrm{B}_{\mathrm{HS}}$ and $\mathrm{C}_{\mathrm{HS}}$, respectively. Evaluating stations in the state of Minas Gerais, Ferreira et al. (2018), found when the parameters $\mathrm{A}_{\mathrm{HS}}, \mathrm{B}_{\mathrm{HS}}$ and $\mathrm{C}_{\mathrm{HS}}$ 
was simultaneously calibrated, the values of parameters $\mathrm{A}_{\mathrm{HS}}, \mathrm{B}_{\mathrm{HS}}$ and $\mathrm{C}_{\mathrm{HS}}$ ranged from 0.0011 to $0.0023,1.1669$ to 15.5731 and 0.6128 to 0.8312 , respectively.

The variations of the $\mathrm{A}_{\mathrm{MP}}, \mathrm{B}_{\mathrm{MP}}, \mathrm{C}_{\mathrm{MP}}, \mathrm{D}_{\mathrm{MP}}$ and $\mathrm{E}_{\mathrm{MP}}$ coefficients were, respectively, 0.000616 to 0.086037 ,
-0.000359 to $0.000129,-3.841521$ and 2.929596 , -0.043671 to 0.064424 and -2.532777 to 4.474882 . This range value occurs due to the calibration site specific for each station studied; the smallest errors occurred with these coefficients for each station.

Table 2: $A_{H S^{\prime}} B_{H S}$ coefficients and $C_{H S}$ exponent of the Hargreaves-Samani equation calibrated locally for each conventional weather station.

\begin{tabular}{|c|c|c|c|}
\hline \multirow{2}{*}{ Stations } & \multicolumn{3}{|c|}{ Coefficients } \\
\hline & $\mathrm{A}_{\mathrm{HS}}$ & $\mathrm{B}_{\mathrm{HS}}$ & $\mathrm{C}_{\mathrm{HS}}$ \\
\hline Aimorés & 0.002381 & -4.844 & 0.6938 \\
\hline Araçuaí & 0.003050 & -2.048 & 0.5306 \\
\hline Araxá & 0.001318 & 8.476 & 0.7836 \\
\hline Arinos & 0.002234 & 2.923 & 0.5760 \\
\hline Bambuí & 0.001687 & 3.819 & 0.6473 \\
\hline Barbacena & 0.001443 & 10.771 & 0.6639 \\
\hline Belo Horizonte & 0.002551 & 8.465 & 0.5275 \\
\hline Bom Despacho & 0.002363 & 0.000 & 0.5787 \\
\hline C. do Mato Dentro & 0.002493 & 2.725 & 0.5316 \\
\hline Caparaó & 0.002871 & -0.338 & 0.5607 \\
\hline Capinópolis & 0.001558 & 8.591 & 0.6860 \\
\hline Caratinga & 0.002676 & -2.590 & 0.6449 \\
\hline Cel. Pacheco & 0.002371 & -1.150 & 0.6135 \\
\hline Curvelo & 0.001139 & 3.938 & 0.7882 \\
\hline Diamantina & 0.001101 & 20.608 & 0.7364 \\
\hline Divinópolis & 0.001358 & 6.469 & 0.7588 \\
\hline Espinosa & 0.002613 & 8.834 & 0.5499 \\
\hline Florestal & 0.002104 & 4.942 & 0.5689 \\
\hline Formosa & 0.001516 & 12.949 & 0.6646 \\
\hline Formoso & 0.000670 & 30.758 & 0.8061 \\
\hline Frutal & 0.002083 & 6.000 & 0.5892 \\
\hline Guaratinga & 0.002295 & 0.089 & 0.6787 \\
\hline Ibirité & 0.002396 & 5.031 & 0.5198 \\
\hline Itamarandiba & 0.001972 & 10.616 & 0.5398 \\
\hline Ituiutaba & 0.002297 & 1.657 & 0.5779 \\
\hline Janaúba & 0.002080 & 36.812 & 0.3431 \\
\hline Januária & 0.001951 & 4.722 & 0.6615 \\
\hline João Pinheiro & 0.002119 & 3.334 & 0.6584 \\
\hline Juiz de Fora & 0.001647 & 10.842 & 0.6442 \\
\hline Juramento & 0.002397 & 6.001 & 0.5367 \\
\hline
\end{tabular}

Continue... 
Table 2: Continuation.

\begin{tabular}{cccc}
\hline Stations & \multicolumn{3}{c}{ Coefficients } \\
\cline { 2 - 4 } & $\mathrm{A}_{\mathrm{HS}}$ & \multicolumn{1}{c}{$\mathrm{B}_{\mathrm{HS}}$} & 0.6760 \\
\hline Lambari & 0.001283 & 10.519 & 0.7358 \\
Lavras & 0.001286 & 4.913 & 0.6070 \\
Machado & 0.001909 & 7.970 & 0.6372 \\
Mocambinho & 0.001764 & 18.054 & 0.5537 \\
Monte Azul & 0.002014 & 7.825 & 0.6748 \\
Montes Claros & 0.001739 & 5.131 & 0.5197 \\
P. de Caldas & 0.002430 & 18.636 & 0.7575 \\
Patos de Minas & 0.001000 & -1.406 & 0.7647 \\
Paracatu & 0.001898 & -0.699 & 0.5776 \\
Paranaíba & 0.002683 & 1.671 & 0.5396 \\
Pedra Azul & 0.002959 & 0.000 & 0.6070 \\
Pirapora & 0.002551 & 0.000 & 0.6282 \\
Pompéu & 0.002267 & -1.557 & 0.6335 \\
Salinas & 0.002423 & 1.152 & 0.5986 \\
São Lourenço & 0.002296 & -6.546 & 0.6451 \\
São Mateus & 0.003282 & 7.586 & 0.5590 \\
São S. do Paraíso & 0.002077 & 9.071 & 0.6484 \\
Sete Lagoas & 0.001661 & 5.357 & 0.6875 \\
Uberaba & 0.001707 & 0.000 & 0.6307 \\
Unaí & 0.002176 & 1.232 & 0.6154 \\
Viçosa & 0.002325 & -2.534 & 0.5511 \\
Vitória & 0.004116 & & \\
\hline & & & \\
\hline & & & \\
\hline
\end{tabular}

Table 3: Coefficients $A_{M P^{\prime}} B_{M P^{\prime}} C_{M P^{\prime}} D_{M P}$ and $E_{M P}$ of the Proposed Method calibrated locally for each conventional weather station.

\begin{tabular}{clcrrr}
\hline \multirow{2}{*}{ Stations } & \multicolumn{5}{c}{ Coefficients } \\
\cline { 2 - 6 } & \multicolumn{1}{c}{$\mathrm{A}_{\mathrm{MP}}$} & $\mathrm{B}_{\mathrm{MP}}$ & $\mathrm{C}_{\mathrm{MP}}$ & \multicolumn{1}{c}{$\mathrm{D}_{\mathrm{MP}}$} & \multicolumn{1}{c}{$\mathrm{E}_{\mathrm{MP}}$} \\
\hline Aimorés & 0.001163 & -0.000064 & -2.677941 & 0.057457 & 2.432574 \\
Araçuaí & 0.000838 & -0.000062 & -2.408044 & 0.04904 & 2.987566 \\
Araxá & 0.000935 & -0.000089 & -3.363896 & 0.046952 & 3.519001 \\
Arinos & 0.086037 & -0.000007 & -0.234781 & 0.003001 & 0.229938 \\
Bambuí & 0.055791 & 0.000002 & 0.186176 & -0.001757 & -0.222880 \\
Barbacena & 0.001 & -0.000056 & -2.447916 & 0.033057 & 3.155007 \\
Belo Horizonte & 0.033999 & -0.000021 & -0.339693 & 0.004366 & 0.406494 \\
Bom Despacho & 0.024520 & -0.000003 & -0.263188 & 0.005971 & 0.320664 \\
C. do Mato Dentro & 0.000837 & -0.000021 & -1.743834 & 0.037337 & 2.927549 \\
\hline
\end{tabular}


Table 3: Continuation.

\begin{tabular}{|c|c|c|c|c|c|}
\hline \multirow{2}{*}{ Stations } & \multicolumn{5}{|c|}{ Coefficients } \\
\hline & $A_{M P}$ & $B_{M P}$ & $\mathrm{C}_{\mathrm{MP}}$ & $\mathrm{D}_{\mathrm{MP}}$ & $\mathrm{E}_{\mathrm{MP}}$ \\
\hline Caparaó & 0.000892 & -0.000027 & -1.875859 & 0.050593 & 2.719342 \\
\hline Capinópolis & 0.000921 & -0.000112 & -3.71363 & 0.047824 & 3.615388 \\
\hline Caratinga & 0.001106 & -0.000045 & -2.231497 & 0.058567 & 2.414097 \\
\hline Cel. Pacheco & 0.001239 & -0.000019 & -1.696852 & 0.044582 & 2.164268 \\
\hline Curvelo & 0.085881 & -0.000003 & -0.219276 & 0.003433 & 0.192770 \\
\hline Diamantina & 0.00069 & -0.000141 & -3.717841 & 0.039875 & 4.474882 \\
\hline Divinópolis & 0.073683 & 0.000003 & 0.217847 & -0.00303 & -0.236334 \\
\hline Espinosa & 0.079055 & 0.000017 & 0.337120 & -0.003476 & -0.316328 \\
\hline Florestal & 0.031936 & -0.000004 & -0.239533 & 0.003769 & 0.330556 \\
\hline Formosa & 0.000744 & -0.000149 & -3.841521 & 0.043265 & 4.259608 \\
\hline Formoso & 0.005430 & 0.000023 & 1.022224 & -0.008010 & -1.054547 \\
\hline Frutal & 0.000946 & -0.0001 & -3.084723 & 0.042207 & 3.402767 \\
\hline Guaratinga & 0.001314 & -0.000079 & -2.488216 & 0.045826 & 2.694635 \\
\hline Ibirité & 0.049390 & 0.000004 & 0.186176 & -0.002915 & -0.270576 \\
\hline Itamarandiba & 0.000823 & -0.000056 & -2.196894 & 0.024777 & 3.567307 \\
\hline Ituiutaba & 0.000616 & -0.000066 & -3.057873 & 0.049521 & 3.729945 \\
\hline Janaúba & 0.023533 & 0.000018 & 0.435228 & -0.001071 & -0.587648 \\
\hline Januária & 0.002142 & 0.000035 & 1.461719 & -0.018785 & -1.520345 \\
\hline João Pinheiro & 0.000788 & 0.000129 & 2.929596 & -0.043671 & -2.532777 \\
\hline Juiz de Fora & 0.001048 & -0.000093 & -2.581779 & 0.031906 & 3.347468 \\
\hline Juramento & 0.004038 & 0.000019 & 0.781409 & -0.012007 & -0.993004 \\
\hline Lambari & 0.001064 & 0.000004 & -1.370662 & 0.030071 & 2.245665 \\
\hline Lavras & 0.001148 & -0.00006 & -2.791125 & 0.037883 & 3.075116 \\
\hline Machado & 0.000921 & -0.000051 & -2.336182 & 0.040775 & 2.976226 \\
\hline Mocambinho & 0.004427 & 0.000030 & 1.074686 & -0.012658 & -1.073795 \\
\hline Monte Azul & 0.002709 & 0.000108 & 1.764537 & -0.016490 & -1.754594 \\
\hline Montes Claros & 0.029163 & 0.000011 & 0.392075 & -0.005391 & -0.407911 \\
\hline P. de Caldas & 0.001027 & -0.000033 & -1.721197 & 0.02871 & 2.893956 \\
\hline Patos de Minas & 0.002008 & -0.000068 & -2.355955 & 0.023742 & 2.57359 \\
\hline Paracatu & 0.004868 & 0.000031 & 1.104948 & -0.018926 & -0.906715 \\
\hline Paranaíba & 0.00082 & -0.000115 & -3.412543 & 0.061931 & 3.257013 \\
\hline Pedra Azul & 0.00067 & -0.000123 & -3.224657 & 0.054946 & 3.898238 \\
\hline Pirapora & 0.007477 & 0.000018 & 0.692383 & -0.011974 & -0.712772 \\
\hline Pompéu & 0.000987 & -0.000047 & -1.757979 & 0.033381 & 1.825659 \\
\hline Salinas & 0.001202 & -0.000022 & -1.936631 & 0.044653 & 2.366196 \\
\hline São Lourenço & 0.000882 & -0.000027 & -2.127842 & 0.049072 & 2.757288 \\
\hline
\end{tabular}


Table 3: Continuation.

\begin{tabular}{cccccc}
\hline Stations & \multicolumn{5}{c}{ Coefficients } \\
\cline { 2 - 6 } & $\mathrm{A}_{\mathrm{MP}}$ & $\mathrm{B}_{\mathrm{MP}}$ & $\mathrm{C}_{\mathrm{MP}}$ & $\mathrm{D}_{\mathrm{MP}}$ & \multicolumn{1}{c}{$\mathrm{E}_{\mathrm{MP}}$} \\
\hline São Mateus & 0.00127 & -0.000137 & -2.886563 & 0.064424 & 2.47882 \\
São S. do Paraíso & 0.001062 & -0.00006 & -2.358875 & 0.033185 & 3.059147 \\
Sete Lagoas & 0.003052 & -0.000036 & -1.211879 & 0.015275 & 1.257290 \\
Uberaba & 0.000695 & -0.000091 & -3.817426 & 0.052157 & 3.962464 \\
Unaí & 0.027208 & -0.000010 & -0.382626 & 0.006760 & 0.352244 \\
Viçosa & 0.000918 & -0.000031 & -2.054849 & 0.046971 & 2.811409 \\
Vitória & 0.001058 & -0.000359 & -3.462278 & 0.060349 & 3.602808 \\
\hline
\end{tabular}

\section{Analysis of descriptive statistics}

Tables 4 and 5 show the maximum, minimum and mean $\mathrm{ET}_{0}$ values and respective standard deviation values and coefficients of variation for each conventional weather station for FAO-PM, original HS, HScal and MP methods.

It can be observed that for the FAO-PM method, the upper and lower limits of the $\mathrm{ET}_{0}$ were $10.82 \mathrm{~mm} \mathrm{~d}^{-1}$ in Espinosa and $5.83 \mathrm{~mm} \mathrm{~d}^{-1}$ in Poços de Caldas for maximum values and $1.45 \mathrm{~mm} \mathrm{~d}^{-1}$ in Monte Azul and $0.61 \mathrm{~mm} \mathrm{~d}^{-1}$ in Juiz de for minimum values. For the HS method, the upper and lower limits of the $\mathrm{ET}_{0}$ were $8.57 \mathrm{~mm} \mathrm{~d}^{-1}$ in Arinos and $6.76 \mathrm{~mm} \mathrm{~d}^{-1}$ in Diamantina for maximum values and 2.09 $\mathrm{mm} \mathrm{d}^{-1}$ in Juramento and $0.51 \mathrm{~mm} \mathrm{~d}^{-1}$ in Juiz de for minimum values. In relation to the mean values, the extremes were $4.85 \mathrm{~mm} \mathrm{~d}^{-1}$ in Espinosa and $2.81 \mathrm{~mm} \mathrm{~d}^{-1}$ in Lambari, for the FAO-PM method, and $5.14 \mathrm{~mm} \mathrm{~d}^{-1}$ in Mocambinho and $3.70 \mathrm{~mm} \mathrm{~d}^{-1}$ in Vitória-ES for the HS method.

The overestimation bias of the $\mathrm{ET}_{0}$ by the HS method was highlighted in 49 of the 52 stations studied, being the exception verified for Espinosa-MG, Monte Azul-MG and Vitória-ES stations. This result can be explained by the location of the stations in a region subject to high wind speed values.

Some authors have found overestimation of $\mathrm{ET}_{0}$ by HS in humid environments and underestimation in very windy conditions compared to the standard FAO-PM method (Allen et al., 1998; Djaman et al., 2015; Droogers; Allen, 2002).

In Table 5, for the HScal method, it is observed that the limit values of the maximum $\mathrm{ET}_{0}$ were $9.13 \mathrm{~mm}$ $\mathrm{d}^{-1}$ for Vitória-ES and $5.44 \mathrm{~mm} \mathrm{~d}^{-1}$ for Poços de Caldas. For the minimum $\mathrm{ET}_{0}$, the limits were $2.15 \mathrm{~mm} \mathrm{~d}^{-1}$ for Janaúba and $0.23 \mathrm{~mm} \mathrm{~d}^{-1}$ for Juiz de Fora. For MP, the extremes of $\mathrm{ET}_{0}$ maximum were $7.71 \mathrm{~mm} \mathrm{~d}^{-1}$ for Aimorés and $5.35 \mathrm{~mm} \mathrm{~d}^{-1}$ for Poços de Caldas and extreme values of minimum $\mathrm{ET}_{0}$ were $0.03 \mathrm{~mm} \mathrm{~d}^{-1}$ for João Pinheiro and $1.27 \mathrm{~mm} \mathrm{~d}^{-1}$ for Juramento.

In view of this, it was verified the local calibrations of the HS and MP methods considerably approached the $\mathrm{ET}_{0}$ averages to the FAO-PM standard method for all stations studied.

Statistical measures and indices relating to performance analysis of alternative methods are presented in Tables 6 and 7. After analysis of the mean absolute error (MAE) present in Table 6, it was verified that, for all the conventional stations studied, the MP performance was superior to the other two methods.

The MAE variation for the HS and HScal methods was from $0.59 \mathrm{~mm} \mathrm{~d}^{-1}$ (Diamantina) to $2.01 \mathrm{~mm} \mathrm{~d}^{-1}$ (Lambari) and from $0.34 \mathrm{~mm} \mathrm{~d}^{-1}$ (São Lourenço) to 0.88 $\mathrm{mm} \mathrm{d}^{-1}$ (Monte Azul), respectively, evidencing a large reduction in the MAE value after the local calibration of the HS method. For most stations studied, more than 50\% reduction in mean absolute error values was obtained.

Pandey et al. (2014) verified that the parametric calibration of the HS equation provided a reduction in the MAE between 0.442 to $0.621 \mathrm{~mm} \mathrm{~d}^{-1}$ for the wet region in India. Zhao et al. (2015) adjusted the HS equation on a monthly basis by means of linear regression for the North, Northeast and Northwest regions of China, and obtained a reduction in the MAE of 9.3, 9.6 and $10.8 \mathrm{~mm}$ month $^{-1}$, respectively.

Martí et al. (2015a), modeling $\mathrm{ET}_{0}$ at two stations in Spain between 2007 and 2012, observed improvements of $0.476 \mathrm{~mm} \mathrm{~d}^{-1}$ in the MAE after the local calibration of the HS method. Likewise, Martí et al. (2015b) analyzed the performance of calibrated and non-calibrated HS equations at 30 stations in Eastern Spain at daily, weekly, fortnightly and monthly scales. The MAE values decreased for locally calibrated models for all stations in the study. 
Table 4: Descriptive statistics with maximum (Max) and minimum (Min) values, mean (med), standard deviation $(\mathrm{sd})$, in $\mathrm{mm} \mathrm{d}^{-1}$, and coefficients of variation (cv, \%), of the FAO Penman-Monteith (FAO-PM) and original HargreavesSamani (HS) methods.

\begin{tabular}{|c|c|c|c|c|c|c|c|c|c|c|}
\hline \multirow{2}{*}{ Stations } & \multicolumn{5}{|c|}{$\mathrm{ET}_{0} \mathrm{FAO}-\mathrm{PM}$} & \multicolumn{5}{|c|}{$\mathrm{ET}_{0} \mathrm{HS}$} \\
\hline & Max & Min & Med & $\mathrm{sd}$ & $\mathrm{cV}$ & Max & Min & Med & $\mathrm{sd}$ & $\mathrm{cV}$ \\
\hline Aimorés & 7.86 & 1.13 & 3.84 & 1.32 & 34.25 & 8.35 & 1.45 & 4.77 & 1.187 & 24.89 \\
\hline Araçuaí & 7.74 & 1.15 & 3.79 & 1.19 & 31.45 & 8.37 & 1.42 & 4.85 & 1.171 & 24.15 \\
\hline Araxá & 7.92 & 0.82 & 3.62 & 1.14 & 31.44 & 7.00 & 0.98 & 4.14 & 1.019 & 24.62 \\
\hline Arinos & 7.97 & 1.37 & 3.97 & 1.09 & 27.58 & 8.57 & 1.85 & 5.05 & 1.05 & 20.75 \\
\hline Bambuí & 6.55 & 1.05 & 3.28 & 1.10 & 33.39 & 8.02 & 1.30 & 4.67 & 1.11 & 23.74 \\
\hline Barbacena & 6.27 & 0.71 & 2.94 & 1.09 & 37.05 & 6.91 & 0.71 & 3.87 & 1.129 & 29.18 \\
\hline Belo Horizonte & 7.70 & 1.03 & 3.66 & 1.13 & 30.90 & 6.94 & 1.04 & 4.01 & 1.03 & 25.74 \\
\hline Bom Despacho & 6.56 & 1.19 & 3.58 & 1.11 & 31.01 & 8.23 & 1.43 & 5.05 & 1.18 & 23.32 \\
\hline C.do Mato Dentro & 7.16 & 1.08 & 3.33 & 1.13 & 33.85 & 8.12 & 1.03 & 4.49 & 1.197 & 26.66 \\
\hline Caparaó & 7.13 & 1.04 & 3.23 & 1.17 & 36.25 & 7.49 & 1.11 & 4.18 & 1.123 & 26.86 \\
\hline Capinópolis & 9.45 & 0.87 & 4.05 & 1.20 & 29.56 & 8.01 & 1.26 & 4.76 & 1.074 & 22.55 \\
\hline Caratinga & 8.02 & 1.05 & 3.42 & 1.23 & 35.89 & 7.68 & 1.30 & 4.19 & 1.059 & 25.28 \\
\hline Cel. Pacheco & 6.87 & 0.94 & 3.18 & 1.18 & 37.05 & 8.07 & 1.11 & 4.38 & 1.201 & 27.41 \\
\hline Curvelo & 7.98 & 1.10 & 3.46 & 1.17 & 33.93 & 7.82 & 1.54 & 4.90 & 1.10 & 22.43 \\
\hline Diamantina & 7.11 & 1.05 & 3.28 & 1.08 & 32.91 & 6.76 & 1.21 & 3.71 & 0.957 & 25.77 \\
\hline Divinópolis & 7.95 & 1.04 & 3.88 & 1.27 & 32.70 & 7.55 & 1.32 & 4.62 & 1.13 & 24.34 \\
\hline Espinosa & 10.82 & 1.37 & 4.85 & 1.43 & 29.48 & 7.59 & 1.78 & 4.68 & 0.99 & 21.06 \\
\hline Florestal & 6.99 & 1.10 & 3.41 & 1.03 & 30.15 & 7.72 & 1.25 & 4.63 & 1.10 & 23.80 \\
\hline Formosa & 7.62 & 1.29 & 3.75 & 1.02 & 27.07 & 7.90 & 1.36 & 4.32 & 0.890 & 20.58 \\
\hline Formoso & 7.33 & 1.38 & 3.97 & 1.09 & 27.46 & 7.89 & 1.71 & 4.82 & 0.98 & 20.27 \\
\hline Frutal & 7.86 & 1.04 & 3.90 & 1.16 & 29.79 & 7.84 & 1.04 & 4.75 & 1.139 & 23.97 \\
\hline Guaratinga & 7.35 & 1.22 & 3.69 & 1.27 & 34.51 & 7.31 & 1.38 & 4.25 & 1.136 & 26.71 \\
\hline Ibirité & 6.95 & 1.11 & 3.33 & 1.09 & 32.68 & 7.70 & 1.39 & 4.48 & 1.08 & 24.21 \\
\hline Itamarandiba & 6.12 & 1.05 & 3.18 & 1.03 & 32.27 & 7.13 & 1.18 & 4.09 & 1.098 & 26.85 \\
\hline Ituiutaba & 8.38 & 1.18 & 3.81 & 1.09 & 28.59 & 8.09 & 1.06 & 4.96 & 1.091 & 22.00 \\
\hline Janaúba & 10.62 & 1.29 & 4.42 & 1.18 & 26.73 & 8.25 & 1.86 & 4.96 & 1.12 & 22.68 \\
\hline Januária & 9.75 & 1.35 & 4.48 & 1.25 & 27.91 & 8.04 & 1.84 & 4.99 & 1.01 & 20.15 \\
\hline João Pinheiro & 7.76 & 0.87 & 4.00 & 1.12 & 27.91 & 8.29 & 1.23 & 4.53 & 0.98 & 21.60 \\
\hline Juiz de Fora & 7.94 & 0.61 & 3.09 & 1.25 & 40.29 & 7.24 & 0.51 & 3.73 & 1.204 & 32.31 \\
\hline Juramento & 8.15 & 1.24 & 3.88 & 1.09 & 28.15 & 8.07 & 2.09 & 4.75 & 1.03 & 21.72 \\
\hline Lambari & 5.99 & 0.93 & 2.81 & 1.02 & 36.39 & 8.23 & 1.46 & 4.82 & 1.283 & 26.63 \\
\hline Lavras & 7.20 & 0.90 & 3.53 & 1.21 & 34.30 & 7.35 & 1.15 & 4.23 & 1.154 & 27.24 \\
\hline Machado & 7.24 & 0.89 & 3.13 & 1.07 & 34.06 & 7.76 & 0.97 & 4.28 & 1.143 & 26.70 \\
\hline Mocambinho & 8.65 & 1.31 & 4.36 & 1.15 & 26.36 & 8.13 & 1.12 & 5.14 & 1.02 & 19.92 \\
\hline Monte Azul & 10.65 & 1.45 & 4.70 & 1.36 & 28.96 & 7.41 & 1.48 & 4.59 & 1.01 & 21.96 \\
\hline
\end{tabular}


Table 4: Continuation.

\begin{tabular}{ccccccccccc}
\hline \multirow{2}{*}{ Stations } & \multicolumn{3}{c}{$\mathrm{ET}_{0}$ FAO-PM } & \multicolumn{7}{c}{$\mathrm{ET}_{0} \mathrm{HS}$} \\
\cline { 2 - 10 } & Max & Min & Med & sd & CV & Max & Min & Med & sd & cV \\
\hline Montes Claros & 8.48 & 1.38 & 4.16 & 1.23 & 29.60 & 7.81 & 1.57 & 4.64 & 1.00 & 21.65 \\
P. de Caldas & 5.83 & 0.88 & 2.95 & 0.98 & 33.30 & 7.03 & 0.89 & 4.01 & 1.052 & 26.25 \\
Patos de Minas & 8.36 & 1.14 & 3.72 & 1.11 & 29.84 & 8.09 & 1.29 & 4.37 & 0.983 & 22.48 \\
Paracatu & 7.57 & 1.03 & 3.61 & 1.12 & 30.94 & 6.94 & 1.04 & 4.06 & 1.02 & 25.20 \\
Paranaíba & 7.87 & 0.92 & 3.84 & 1.22 & 31.79 & 8.01 & 1.23 & 4.75 & 1.119 & 23.55 \\
Pedra Azul & 8.12 & 1.25 & 3.69 & 1.21 & 32.87 & 7.53 & 1.55 & 4.31 & 1.107 & 25.68 \\
Pirapora & 8.90 & 1.15 & 4.15 & 1.22 & 29.44 & 8.13 & 1.40 & 4.84 & 1.01 & 20.79 \\
Pompéu & 7.11 & 1.07 & 3.55 & 1.11 & 31.18 & 7.78 & 1.47 & 4.61 & 1.05 & 22.76 \\
Salinas & 8.10 & 1.32 & 3.86 & 1.28 & 33.22 & 8.05 & 1.43 & 4.78 & 1.163 & 24.33 \\
São Lourenço & 6.78 & 0.91 & 3.23 & 1.16 & 35.95 & 8.20 & 1.07 & 4.40 & 1.199 & 27.27 \\
São Mateus & 7.07 & 1.14 & 3.50 & 1.21 & 34.45 & 7.22 & 1.53 & 4.20 & 0.959 & 22.84 \\
São S. do Paraíso & 6.76 & 1.00 & 3.46 & 1.10 & 31.71 & 7.55 & 1.03 & 4.44 & 1.109 & 24.98 \\
Sete Lagoas & 8.72 & 1.16 & 3.72 & 1.14 & 30.68 & 7.71 & 1.22 & 4.50 & 1.06 & 23.63 \\
Uberaba & 9.58 & 0.83 & 3.93 & 1.22 & 31.03 & 8.18 & 0.96 & 4.63 & 1.069 & 23.06 \\
Unaín & 8.94 & 1.27 & 3.83 & 1.10 & 28.84 & 8.17 & 1.42 & 4.94 & 1.00 & 20.23 \\
Viçosa & 6.97 & 0.97 & 3.17 & 1.17 & 37.03 & 7.83 & 0.84 & 4.09 & 1.152 & 28.15 \\
Vitória & 8.55 & 1.08 & 3.87 & 1.43 & 36.85 & 7.56 & 1.10 & 3.70 & 1.085 & 29.32 \\
\hline
\end{tabular}

Table 5: Descriptive statistics with maximum (Max) and minimum values (Min), mean (med), standard deviation (sd), in $\mathrm{mm} \mathrm{d}^{-1}$, and coefficients of variation (cv, \%), of the Hargreaves-Samani calibrated (HScal) and Proposed Method (MP).

\begin{tabular}{cccccccccccc}
\hline \multirow{2}{*}{ Stations } & \multicolumn{9}{c}{$\mathrm{ET}_{0} \mathrm{HSCal}$} \\
\cline { 2 - 11 } & $\mathrm{Max}$ & $\mathrm{Min}$ & $\mathrm{Med}$ & $\mathrm{sd}$ & $\mathrm{cV}$ & $\mathrm{Max}$ & $\mathrm{Min}$ & $\mathrm{Med}$ & $\mathrm{sd}$ & $\mathrm{CV}$ \\
\hline Aimorés & 8.49 & 0.67 & 3.85 & 1.24 & 32.26 & 7.71 & 0.54 & 3.86 & 1.25 & 32.37 \\
Araçuaí & 7.12 & 0.91 & 3.78 & 1.07 & 28.34 & 6.88 & 0.80 & 3.79 & 1.08 & 28.59 \\
Araxá & 7.13 & 0.46 & 3.57 & 1.05 & 29.44 & 6.45 & 0.34 & 3.57 & 1.04 & 29.14 \\
Arinos & 7.09 & 1.22 & 3.93 & 0.94 & 23.92 & 6.28 & 0.45 & 3.95 & 0.96 & 24.17 \\
Bambuí & 6.45 & 0.64 & 3.27 & 0.92 & 28.03 & 6.05 & 0.57 & 3.27 & 0.93 & 28.34 \\
Barbacena & 5.77 & 0.35 & 2.92 & 0.96 & 32.99 & 5.53 & 0.27 & 2.93 & 0.97 & 33.18 \\
Belo Horizonte & 6.64 & 0.82 & 3.64 & 1.00 & 27.49 & 6.64 & 0.82 & 3.64 & 1.03 & 28.17 \\
Bom Despacho & 6.58 & 0.77 & 3.59 & 1.01 & 28.05 & 6.59 & 0.63 & 3.57 & 1.02 & 28.43 \\
C. do Mato Dentro & 6.57 & 0.66 & 3.28 & 0.99 & 30.31 & 6.49 & 0.74 & 3.28 & 0.99 & 30.32 \\
Caparaó & 6.73 & 0.67 & 3.20 & 1.05 & 32.90 & 6.52 & 0.64 & 3.21 & 1.06 & 32.94 \\
Capinópolis & 7.62 & 0.72 & 4.02 & 1.04 & 25.92 & 6.91 & 0.41 & 4.02 & 1.05 & 25.92 \\
Caratinga & 7.55 & 0.71 & 3.40 & 1.10 & 32.32 & 7.15 & 0.62 & 3.40 & 1.11 & 32.51 \\
Cel. Pacheco & 6.86 & 0.53 & 3.17 & 1.08 & 34.00 & 6.73 & 0.49 & 3.18 & 1.09 & 34.18 \\
Curvelo & 6.46 & 0.66 & 3.46 & 0.96 & 27.59 & 6.25 & 0.46 & 3.51 & 0.98 & 28.02 \\
Diamantina & 7.00 & 0.60 & 3.26 & 0.95 & 29.18 & 5.76 & 0.64 & 3.27 & 0.95 & 29.17 \\
\hline
\end{tabular}


Table 5: Continuation.

\begin{tabular}{|c|c|c|c|c|c|c|c|c|c|c|}
\hline \multirow{2}{*}{ Stations } & \multicolumn{5}{|c|}{$\mathrm{ET}_{0} \mathrm{HScal}$} & \multicolumn{5}{|c|}{$\mathrm{ET}_{0} \mathrm{MP}$} \\
\hline & Max & Min & Med & $\mathrm{sd}$ & $\mathrm{CV}$ & Max & Min & Med & $\mathrm{sd}$ & $\mathrm{CV}$ \\
\hline Divinópolis & 7.35 & 0.66 & 3.83 & 1.11 & 29.09 & 6.82 & 0.53 & 3.83 & 1.10 & 28.75 \\
\hline Espinosa & 8.08 & 1.59 & 4.76 & 1.08 & 22.75 & 7.23 & 0.11 & 4.74 & 1.16 & 24.47 \\
\hline Florestal & 6.18 & 0.74 & 3.41 & 0.92 & 27.12 & 5.93 & 0.62 & 3.40 & 0.93 & 27.27 \\
\hline Formosa & 7.59 & 0.87 & 3.71 & 0.88 & 23.65 & 6.10 & 0.64 & 3.71 & 0.87 & 23.65 \\
\hline Formoso & 8.25 & 0.78 & 3.97 & 0.97 & 24.36 & 6.44 & 0.48 & 3.98 & 0.97 & 24.40 \\
\hline Frutal & 6.99 & 0.66 & 3.91 & 1.05 & 26.71 & 6.73 & 0.46 & 3.90 & 1.07 & 27.28 \\
\hline Guaratinga & 7.47 & 0.86 & 3.72 & 1.23 & 33.14 & 7.12 & 0.81 & 3.73 & 1.24 & 33.36 \\
\hline Ibirité & 5.95 & 0.91 & 3.31 & 0.89 & 26.96 & 5.66 & 0.78 & 3.34 & 0.90 & 26.98 \\
\hline Itamarandiba & 5.73 & 0.81 & 3.14 & 0.90 & 28.71 & 5.46 & 0.72 & 3.15 & 0.91 & 28.78 \\
\hline Ituiutaba & 6.78 & 0.61 & 3.78 & 0.96 & 25.46 & 6.37 & 0.51 & 3.77 & 0.95 & 25.33 \\
\hline Janaúba & 6.45 & 2.15 & 4.34 & 0.84 & 19.37 & 5.88 & 0.04 & 4.30 & 0.92 & 21.36 \\
\hline Januária & 8.02 & 1.16 & 4.46 & 1.08 & 24.21 & 7.38 & 0.85 & 4.46 & 1.08 & 24.22 \\
\hline João Pinheiro & 8.32 & 0.74 & 4.02 & 1.02 & 25.40 & 6.71 & 0.03 & 4.02 & 1.03 & 25.52 \\
\hline Juiz de Fora & 6.57 & 0.23 & 3.03 & 1.11 & 36.59 & 6.13 & 0.36 & 3.04 & 1.11 & 36.57 \\
\hline Juramento & 7.02 & 1.55 & 3.88 & 0.93 & 23.86 & 6.43 & 1.27 & 3.87 & 0.94 & 24.31 \\
\hline Lambari & 5.54 & 0.61 & 2.85 & 0.90 & 31.50 & 5.59 & 0.65 & 2.85 & 0.89 & 31.36 \\
\hline Lavras & 6.88 & 0.62 & 3.51 & 1.10 & 31.26 & 6.41 & 0.48 & 3.51 & 1.10 & 31.45 \\
\hline Machado & 6.31 & 0.50 & 3.11 & 0.95 & 30.66 & 5.81 & 0.40 & 3.10 & 0.96 & 30.84 \\
\hline Mocambinho & 7.72 & 2.14 & 4.45 & 0.89 & 19.95 & 6.66 & 0.37 & 4.33 & 1.00 & 23.16 \\
\hline Monte Azul & 7.62 & 1.30 & 4.59 & 1.05 & 22.77 & 6.82 & 0.57 & 4.58 & 1.10 & 23.96 \\
\hline Montes Claros & 7.76 & 0.91 & 4.12 & 1.05 & 25.46 & 6.98 & 0.72 & 4.12 & 1.07 & 25.89 \\
\hline P. de Caldas & 5.44 & 0.54 & 2.92 & 0.86 & 29.47 & 5.35 & 0.48 & 2.94 & 0.86 & 29.34 \\
\hline Patos de Minas & 7.83 & 0.72 & 3.64 & 0.93 & 25.62 & 6.19 & 0.54 & 3.65 & 0.93 & 25.56 \\
\hline Paracatu & 6.58 & 0.82 & 3.68 & 0.99 & 26.95 & 6.10 & 0.52 & 3.68 & 1.01 & 27.52 \\
\hline Paranaíba & 7.36 & 0.58 & 3.83 & 1.08 & 28.09 & 7.03 & 0.42 & 3.83 & 1.10 & 28.69 \\
\hline Pedra Azul & 7.08 & 1.15 & 3.70 & 1.09 & 29.35 & 6.54 & 0.94 & 3.71 & 1.10 & 29.66 \\
\hline Pirapora & 7.86 & 0.81 & 4.10 & 1.04 & 25.29 & 7.37 & 0.26 & 4.09 & 1.06 & 25.80 \\
\hline Pompéu & 6.92 & 0.79 & 3.55 & 0.98 & 27.70 & 6.16 & 0.62 & 3.57 & 0.99 & 27.80 \\
\hline Salinas & 7.54 & 0.82 & 3.82 & 1.16 & 30.38 & 7.39 & 0.89 & 3.82 & 1.16 & 30.31 \\
\hline São Lourenco & 6.98 & 0.55 & 3.21 & 1.06 & 33.02 & 6.75 & 0.47 & 3.22 & 1.07 & 33.16 \\
\hline São Mateus & 7.59 & 0.89 & 3.57 & 1.04 & 29.25 & 7.15 & 0.73 & 3.57 & 1.05 & 29.34 \\
\hline São S. do Paraíso & 6.25 & 0.67 & 3.45 & 0.94 & 27.31 & 5.92 & 0.52 & 3.46 & 0.95 & 27.61 \\
\hline Sete Lagoas & 7.04 & 0.73 & 3.70 & 0.99 & 26.63 & 6.38 & 0.45 & 3.71 & 1.00 & 26.97 \\
\hline Uberaba & 8.04 & 0.41 & 3.86 & 1.04 & 26.95 & 6.87 & 0.44 & 3.85 & 1.03 & 26.79 \\
\hline Unaí & 7.11 & 0.79 & 3.80 & 0.94 & 24.86 & 6.78 & 0.49 & 3.79 & 0.97 & 25.46 \\
\hline Viçosa & 6.94 & 0.41 & 3.15 & 1.07 & 34.05 & 6.47 & 0.39 & 3.16 & 1.07 & 33.94 \\
\hline Vitória & 9.13 & 0.86 & 3.89 & 1.34 & 34.51 & 7.42 & 0.66 & 3.90 & 1.36 & 34.86 \\
\hline
\end{tabular}


Table 6: Mean absolute error (MAE, $\mathrm{mm} \mathrm{d}^{-1}$ ), root mean square error (RMSE, $\mathrm{mm} \mathrm{d}^{-1}$ ), systematic root mean square error (RMSEs, $\mathrm{mm} \mathrm{d}^{-1}$ ) and unsystematic (RMSEun, $\mathrm{mm} \mathrm{d}^{-1}$ ) for the original Hargreaves-Samani (HS) and calibrated (HScal) and Proposed (MP) estimation methods.

\begin{tabular}{|c|c|c|c|c|c|c|c|c|c|c|c|c|}
\hline \multirow{2}{*}{ Stations } & \multicolumn{3}{|c|}{ EAM } & \multicolumn{3}{|c|}{ RMSE } & \multicolumn{3}{|c|}{ RMSES } & \multicolumn{3}{|c|}{ RMSEns } \\
\hline & HS & HScal & MP & $\mathrm{HS}$ & HScal & MP & $\mathrm{HS}$ & HScal & $\mathrm{MP}$ & $\mathrm{HS}$ & HScal & MP \\
\hline Aimorés & 0.95 & 0.42 & 0.41 & 1.10 & 0.54 & 0.53 & 0.96 & 0.18 & 0.17 & 0.53 & 0.51 & 0.50 \\
\hline Araçuaí & 1.07 & 0.43 & 0.42 & 1.21 & 0.56 & 0.55 & 1.07 & 0.25 & 0.23 & 0.56 & 0.51 & 0.50 \\
\hline Araxá & 0.73 & 0.54 & 0.53 & 0.91 & 0.69 & 0.68 & 0.63 & 0.30 & 0.30 & 0.65 & 0.62 & 0.61 \\
\hline Arinos & 1.13 & 0.53 & 0.48 & 1.30 & 0.68 & 0.64 & 1.12 & 0.36 & 0.32 & 0.66 & 0.58 & 0.56 \\
\hline Bambuí & 1.39 & 0.44 & 0.43 & 1.52 & 0.59 & 0.58 & 1.40 & 0.32 & 0.31 & 0.60 & 0.49 & 0.49 \\
\hline Barbacena & 0.95 & 0.41 & 0.40 & 1.09 & 0.53 & 0.52 & 0.94 & 0.25 & 0.24 & 0.56 & 0.47 & 0.47 \\
\hline Belo Horizonte & 0.61 & 0.53 & 0.51 & 0.77 & 0.68 & 0.66 & 0.46 & 0.33 & 0.29 & 0.62 & 0.59 & 0.59 \\
\hline Bom Despacho & 1.47 & 0.35 & 0.34 & 1.56 & 0.47 & 0.46 & 1.47 & 0.20 & 0.19 & 0.51 & 0.43 & 0.42 \\
\hline C. do Mato Dentro & 1.18 & 0.41 & 0.41 & 1.30 & 0.55 & 0.55 & 1.16 & 0.27 & 0.26 & 0.59 & 0.49 & 0.48 \\
\hline Caparaó & 0.99 & 0.44 & 0.43 & 1.13 & 0.59 & 0.58 & 0.97 & 0.26 & 0.25 & 0.58 & 0.53 & 0.53 \\
\hline Capinópolis & 0.86 & 0.59 & 0.56 & 1.07 & 0.75 & 0.74 & 0.81 & 0.38 & 0.37 & 0.70 & 0.65 & 0.64 \\
\hline Caratinga & 0.83 & 0.44 & 0.43 & 0.97 & 0.58 & 0.57 & 0.82 & 0.26 & 0.25 & 0.51 & 0.51 & 0.51 \\
\hline Cel. Pacheco & 1.21 & 0.41 & 0.40 & 1.33 & 0.54 & 0.53 & 1.21 & 0.22 & 0.21 & 0.57 & 0.49 & 0.49 \\
\hline Curvelo & 1.46 & 0.57 & 0.56 & 1.64 & 0.74 & 0.80 & 1.48 & 0.43 & 0.46 & 0.71 & 0.60 & 0.65 \\
\hline Diamantina & 0.59 & 0.45 & 0.44 & 0.75 & 0.58 & 0.57 & 0.52 & 0.27 & 0.27 & 0.53 & 0.51 & 0.50 \\
\hline Divinópolis & 0.84 & 0.50 & 0.49 & 1.01 & 0.65 & 0.63 & 0.81 & 0.31 & 0.32 & 0.61 & 0.57 & 0.55 \\
\hline Espinosa & 0.87 & 0.87 & 0.80 & 1.09 & 1.07 & 1.02 & 0.80 & 0.71 & 0.61 & 0.74 & 0.80 & 0.81 \\
\hline Florestal & 1.22 & 0.38 & 0.36 & 1.33 & 0.50 & 0.49 & 1.22 & 0.22 & 0.21 & 0.53 & 0.45 & 0.44 \\
\hline Formosa & 0.73 & 0.51 & 0.49 & 0.90 & 0.66 & 0.64 & 0.67 & 0.35 & 0.33 & 0.59 & 0.57 & 0.54 \\
\hline Formoso & 0.91 & 0.52 & 0.50 & 1.11 & 0.67 & 0.64 & 0.91 & 0.32 & 0.30 & 0.63 & 0.59 & 0.56 \\
\hline Frutal & 0.89 & 0.47 & 0.45 & 1.06 & 0.60 & 0.59 & 0.87 & 0.27 & 0.24 & 0.60 & 0.54 & 0.54 \\
\hline Guaratinga & 0.66 & 0.46 & 0.46 & 0.85 & 0.61 & 0.61 & 0.63 & 0.19 & 0.18 & 0.56 & 0.58 & 0.58 \\
\hline Ibirité & 1.19 & 0.52 & 0.50 & 1.37 & 0.69 & 0.68 & 1.18 & 0.40 & 0.38 & 0.69 & 0.56 & 0.56 \\
\hline Itamarandiba & 0.93 & 0.41 & 0.40 & 1.07 & 0.52 & 0.51 & 0.91 & 0.25 & 0.24 & 0.56 & 0.46 & 0.45 \\
\hline Ituiutaba & 1.18 & 0.46 & 0.44 & 1.32 & 0.61 & 0.60 & 1.17 & 0.29 & 0.29 & 0.62 & 0.53 & 0.52 \\
\hline Janaúba & 0.97 & 0.77 & 0.72 & 1.15 & 0.97 & 0.93 & 0.73 & 0.69 & 0.60 & 0.89 & 0.68 & 0.70 \\
\hline Januária & 0.70 & 0.54 & 0.50 & 0.88 & 0.69 & 0.66 & 0.66 & 0.35 & 0.33 & 0.57 & 0.60 & 0.57 \\
\hline João Pinheiro & 0.71 & 0.57 & 0.53 & 0.93 & 0.72 & 0.70 & 0.66 & 0.33 & 0.31 & 0.65 & 0.64 & 0.63 \\
\hline Juiz de Fora & 0.80 & 0.55 & 0.53 & 0.98 & 0.71 & 0.70 & 0.69 & 0.34 & 0.32 & 0.70 & 0.63 & 0.62 \\
\hline Juramento & 0.93 & 0.48 & 0.45 & 1.09 & 0.63 & 0.61 & 0.91 & 0.34 & 0.31 & 0.60 & 0.53 & 0.53 \\
\hline Lambari & 2.01 & 0.43 & 0.43 & 2.13 & 0.58 & 0.58 & 2.01 & 0.28 & 0.29 & 0.73 & 0.51 & 0.50 \\
\hline Lavras & 0.78 & 0.47 & 0.46 & 0.95 & 0.59 & 0.58 & 0.74 & 0.26 & 0.24 & 0.60 & 0.54 & 0.53 \\
\hline Machado & 1.16 & 0.36 & 0.35 & 1.26 & 0.48 & 0.47 & 1.15 & 0.22 & 0.21 & 0.52 & 0.43 & 0.42 \\
\hline Mocambinho & 0.86 & 0.61 & 0.46 & 1.03 & 0.78 & 0.62 & 0.84 & 0.50 & 0.30 & 0.59 & 0.60 & 0.54 \\
\hline Monte Azul & 0.88 & 0.88 & 0.83 & 1.07 & 1.07 & 1.04 & 0.74 & 0.71 & 0.64 & 0.78 & 0.81 & 0.82 \\
\hline
\end{tabular}


Table 6: Continuation.

\begin{tabular}{cccccccccccccc}
\hline \multirow{2}{*}{ Stations } & \multicolumn{3}{c}{ EAM } & \multicolumn{3}{c}{ RMSE } & \multicolumn{3}{c}{ RMSEs } & \multicolumn{3}{c}{ RMSEns } \\
\cline { 2 - 14 } & HS & HScal & MP & HS & HScal & MP & HS & HScal & MP & HS & HScal & MP \\
\hline Montes Claros & 0.68 & 0.52 & 0.50 & 0.84 & 0.67 & 0.65 & 0.62 & 0.36 & 0.33 & 0.57 & 0.57 & 0.56 \\
P. de Caldas & 1.07 & 0.37 & 0.36 & 1.18 & 0.49 & 0.48 & 1.06 & 0.24 & 0.23 & 0.53 & 0.43 & 0.42 \\
Patos de Minas & 0.81 & 0.52 & 0.51 & 0.98 & 0.68 & 0.67 & 0.74 & 0.38 & 0.37 & 0.63 & 0.57 & 0.55 \\
Paracatu & 0.66 & 0.52 & 0.50 & 0.82 & 0.67 & 0.66 & 0.54 & 0.33 & 0.30 & 0.61 & 0.59 & 0.59 \\
Paranaíba & 0.95 & 0.48 & 0.46 & 1.11 & 0.62 & 0.60 & 0.95 & 0.29 & 0.26 & 0.58 & 0.54 & 0.54 \\
Pedra Azul & 0.72 & 0.49 & 0.47 & 0.89 & 0.62 & 0.61 & 0.67 & 0.28 & 0.26 & 0.58 & 0.56 & 0.55 \\
Pirapora & 0.82 & 0.51 & 0.48 & 0.97 & 0.68 & 0.65 & 0.79 & 0.36 & 0.33 & 0.56 & 0.57 & 0.56 \\
Pompéu & 1.08 & 0.44 & 0.42 & 1.22 & 0.59 & 0.57 & 1.08 & 0.27 & 0.26 & 0.57 & 0.52 & 0.51 \\
Salinas & 0.98 & 0.49 & 0.48 & 1.13 & 0.63 & 0.63 & 0.96 & 0.27 & 0.28 & 0.59 & 0.57 & 0.57 \\
São Lourenço & 1.17 & 0.34 & 0.33 & 1.26 & 0.45 & 0.44 & 1.17 & 0.19 & 0.18 & 0.47 & 0.41 & 0.41 \\
São Mateus & 0.83 & 0.59 & 0.58 & 1.06 & 0.79 & 0.78 & 0.85 & 0.41 & 0.40 & 0.63 & 0.67 & 0.66 \\
São S. do Paraíso & 1.00 & 0.45 & 0.44 & 1.16 & 0.59 & 0.58 & 0.99 & 0.30 & 0.29 & 0.60 & 0.51 & 0.50 \\
Sete Lagoas & 0.84 & 0.48 & 0.45 & 1.00 & 0.61 & 0.57 & 0.82 & 0.31 & 0.28 & 0.58 & 0.52 & 0.50 \\
Uberaba & 0.87 & 0.56 & 0.54 & 1.04 & 0.73 & 0.72 & 0.80 & 0.39 & 0.39 & 0.66 & 0.62 & 0.60 \\
Unaín & 1.15 & 0.51 & 0.48 & 1.31 & 0.67 & 0.64 & 1.15 & 0.35 & 0.32 & 0.62 & 0.57 & 0.56 \\
Viçosa & 0.94 & 0.39 & 0.38 & 1.07 & 0.51 & 0.51 & 0.94 & 0.21 & 0.21 & 0.51 & 0.47 & 0.46 \\
Vitória & 0.70 & 0.65 & 0.64 & 0.88 & 0.85 & 0.84 & 0.58 & 0.33 & 0.31 & 0.65 & 0.78 & 0.78 \\
\hline
\end{tabular}

Borges Júnior et al. (2017) evaluated the HS and HS method calibrated at different time scales (annual, semiannual, quarterly, and monthly) for the city of Sete Lagoas$\mathrm{MG}$, and verified that at any time basis, the calibration of the equation significantly reduced the MAE values, making the method more accurate. In a study carried out in Uberaba-MG by Melo and Fernandes (2012), different estimation methods of $\mathrm{ET}_{0}$ were evaluated, comparing with the FAO-PM method, and it was observed that the HS method in its original form reached a value of MAE of $0.96 \mathrm{~mm} \mathrm{~d}^{-1}$, considered high by the authors.

Also, in Table 6, it was verified that for the regionally calibrated MP for each conventional meteorological station, a performance similar to that achieved with the HScal method was obtained. The mean absolute error variation for the MP was 0.33 to $0.83 \mathrm{~mm} \mathrm{~d}^{-1}$ for the Monte Azul and São Lourenço stations, respectively. When compared to HScal, the maximum reduction of MP was $0.07 \mathrm{~mm} \mathrm{~d}^{-1}$; for some stations, there was no reduction in MAE values.

It is observed that RMSE extremes (Table 6) are 0.75 (Diamantina) and $2.13 \mathrm{~mm} \mathrm{~d}^{-1}$ (Lambari) for the HS method and 0.45 (São Lourenço) and $1.07 \mathrm{~mm} \mathrm{~d}^{-1}$ (Monte Azul and Espinosa) for the HScal method. Calibration of the HS method reduced RMSE values in most stations studied. It was verified that RMSE overestimates the magnitude of the mean error when compared to the MAE, as emphasized by Willmott and Matsuura (2005).

For calibrated HS method (one parameter calibrated), Mallikarjuna et al. (2014) obtained RMSE values between 0.64 and $1.07 \mathrm{~mm}$ day $^{-1}$ for five stations in a semiarid climate in India. Berti et al. (2014) worked with the HS method in northwest Italy, calibrating only the $\mathrm{A}_{\mathrm{HS}}$ coefficient to verify its importance in the equation. The authors found that RMSE values were reduced on average about $30 \%$ when compared to the values obtained with the original HS method.

Maestre-Valero et al. (2013), working with 66 modern automatic weather stations in south-eastern Spain, used Hargreaves equation calibrated in two different ways to verify the best fit to the region. They concluded that the regionally calibrated version of the Hargreaves equation clearly improved the performance, reducing the RMSE values for all stations.

When the analysis occurs for the MP, it is verified that the RMSE ranged from 0.44 to $1.04 \mathrm{~mm} \mathrm{~d}^{-1}$ for the São Lourenço and Monte Azul stations, respectively. As observed for the MAE, the reduction relative to the RMSE was maximum of $0.07 \mathrm{~mm} \mathrm{~d}^{-1}$ for the stations studied, when MP is compared with HScal. 
In order to represent the main trends or patterns in the observed values, that is, in the values estimated with the FAO-PM method, the RMSEs should be close to zero, while the RMSEun should be close to RMSE, according to an expected pattern for a "good" model, according to Willmott et al. (2012). It is observed in Table 6 that there were the aforementioned approximations, especially with the calibration of the equations. This fact shows that the values of the estimated equations approached the values calculated by the FAO-PM method.

The correlation coefficients (r) are recorded in Table 7 and express the intensity of the linear association between the studied variables, and the closer to 1 , the association will be more perfect. The values found for the HS, HScal and MP methods ranged from 0.61 to $0.92 ; 0.59$ to 0.92 and 0.64 to 0.92 (Janaúba and São Lourenço), respectively.

In the index of agreement (d), a considerable increase is observed with the calibration of the HS method. The values are between 0.56 (Lambari) to 0.88 (Guaratinga-BA) for the HS method and 0.74 (Janaúba) to 0.96 (São Lourenço) for the HScal method. Regarding MP, the extreme values of d are equal to the HScal method, with a slight increase for the stations in general (maximum of $8.33 \%$ in Mocambinho). The index of agreement averages were 0.80 for the HS method and 0.92 for the HScal and MP methods.

Silva et al. (2012) verified that the performance of the HS method without calibration presented satisfactory results in the 1,3 and 10-day scale for the northern region of the city of Recife-PE, and for the daily scale they obtained values of $\mathrm{r}, \mathrm{d}$, and $\mathrm{C}$ equal to $0.83,0.99,0.83$, classifying the method as "very good". Similarly, Ferreira et al. (2018) evaluating the confidence index (C) and Willmott's index of agreement (d) observed that all calibrations under study promoted an increasing in the indexes, with exception only for Paracatu with calibration of coefficient $\mathrm{A}_{\mathrm{HS}}$. The better performances in the estimation of ETo were found by Arraes et al. (2016) after promote the calibration. For meteorological stations in Poland, Bogawski and Bednorz (2014) obtained d values from 0.80 to 0.93 in testing different configurations for the HS model.

Table 7: Correlation coefficient ( $r$ ), agreement index (d), confidence index (C) for the original Hargreaves-Samani (HS) and calibrated (HScal) and Proposed Method (MP).

\begin{tabular}{|c|c|c|c|c|c|c|c|c|c|}
\hline \multirow{2}{*}{ Stations } & \multicolumn{3}{|c|}{$r$} & \multicolumn{3}{|c|}{ d } & \multicolumn{3}{|c|}{ C } \\
\hline & $\mathrm{HS}$ & HScal & MP & $\mathrm{HS}$ & HScal & MP & $\mathrm{HS}$ & HScal & MP \\
\hline Aimorés & 0.90 & 0.91 & 0.91 & 0.83 & 0.95 & 0.96 & 0.75 & 0.87 & 0.87 \\
\hline Araçuaí & 0.88 & 0.88 & 0.89 & 0.79 & 0.94 & 0.94 & 0.69 & 0.82 & 0.83 \\
\hline Araxá & 0.77 & 0.80 & 0.81 & 0.82 & 0.89 & 0.89 & 0.63 & 0.72 & 0.72 \\
\hline Arinos & 0.78 & 0.79 & 0.81 & 0.72 & 0.88 & 0.89 & 0.56 & 0.69 & 0.73 \\
\hline Bambuí & 0.84 & 0.84 & 0.85 & 0.69 & 0.91 & 0.91 & 0.58 & 0.76 & 0.77 \\
\hline Barbacena & 0.87 & 0.87 & 0.88 & 0.80 & 0.93 & 0.93 & 0.69 & 0.81 & 0.82 \\
\hline Belo Horizonte & 0.80 & 0.81 & 0.82 & 0.87 & 0.89 & 0.90 & 0.69 & 0.72 & 0.74 \\
\hline Bom Despacho & 0.90 & 0.91 & 0.91 & 0.70 & 0.95 & 0.95 & 0.63 & 0.86 & 0.86 \\
\hline C.do Mato Dentro & 0.87 & 0.87 & 0.87 & 0.75 & 0.93 & 0.93 & 0.66 & 0.81 & 0.81 \\
\hline Caparaó & 0.86 & 0.87 & 0.87 & 0.80 & 0.93 & 0.93 & 0.68 & 0.80 & 0.81 \\
\hline Capinópolis & 0.76 & 0.78 & 0.79 & 0.79 & 0.88 & 0.88 & 0.60 & 0.69 & 0.70 \\
\hline Caratinga & 0.88 & 0.88 & 0.89 & 0.84 & 0.94 & 0.94 & 0.74 & 0.83 & 0.83 \\
\hline Cel. Pacheco & 0.88 & 0.89 & 0.89 & 0.76 & 0.94 & 0.94 & 0.67 & 0.84 & 0.84 \\
\hline Curvelo & 0.76 & 0.78 & 0.74 & 0.66 & 0.87 & 0.85 & 0.51 & 0.68 & 0.63 \\
\hline Diamantina & 0.83 & 0.85 & 0.85 & 0.87 & 0.91 & 0.92 & 0.72 & 0.77 & 0.78 \\
\hline Divinópolis & 0.84 & 0.86 & 0.87 & 0.83 & 0.92 & 0.92 & 0.70 & 0.79 & 0.80 \\
\hline Espinosa & 0.66 & 0.67 & 0.71 & 0.77 & 0.79 & 0.83 & 0.51 & 0.53 & 0.59 \\
\hline Florestal & 0.87 & 0.88 & 0.88 & 0.72 & 0.93 & 0.94 & 0.63 & 0.82 & 0.82 \\
\hline
\end{tabular}


Table 7: Continuation.

\begin{tabular}{|c|c|c|c|c|c|c|c|c|c|}
\hline \multirow{2}{*}{ Stations } & \multicolumn{3}{|c|}{$r$} & \multicolumn{3}{|c|}{ d } & \multicolumn{3}{|c|}{ C } \\
\hline & $\mathrm{HS}$ & HScal & $\mathrm{MP}$ & $\mathrm{HS}$ & HScal & $\mathrm{MP}$ & $\mathrm{HS}$ & HScal & $\mathrm{MP}$ \\
\hline Formosa & 0.75 & 0.76 & 0.78 & 0.79 & 0.87 & 0.88 & 0.59 & 0.66 & 0.69 \\
\hline Formoso & 0.76 & 0.80 & 0.81 & 0.76 & 0.89 & 0.90 & 0.58 & 0.71 & 0.73 \\
\hline Frutal & 0.85 & 0.86 & 0.86 & 0.81 & 0.92 & 0.93 & 0.69 & 0.79 & 0.80 \\
\hline Guaratinga & 0.87 & 0.88 & 0.88 & 0.88 & 0.94 & 0.94 & 0.76 & 0.83 & 0.83 \\
\hline Ibirité & 0.77 & 0.78 & 0.78 & 0.70 & 0.87 & 0.88 & 0.54 & 0.68 & 0.69 \\
\hline Itamarandiba & 0.86 & 0.86 & 0.87 & 0.79 & 0.92 & 0.93 & 0.68 & 0.80 & 0.80 \\
\hline Ituiutaba & 0.83 & 0.83 & 0.84 & 0.73 & 0.91 & 0.91 & 0.60 & 0.76 & 0.76 \\
\hline Janaúba & 0.61 & 0.59 & 0.64 & 0.74 & 0.74 & 0.78 & 0.45 & 0.43 & 0.50 \\
\hline Januária & 0.82 & 0.83 & 0.85 & 0.85 & 0.91 & 0.92 & 0.70 & 0.76 & 0.78 \\
\hline João Pinheiro & 0.75 & 0.77 & 0.79 & 0.81 & 0.88 & 0.88 & 0.60 & 0.68 & 0.70 \\
\hline Juiz de Fora & 0.81 & 0.83 & 0.83 & 0.84 & 0.90 & 0.91 & 0.69 & 0.75 & 0.75 \\
\hline Juramento & 0.81 & 0.82 & 0.83 & 0.78 & 0.90 & 0.90 & 0.63 & 0.73 & 0.75 \\
\hline Lambari & 0.82 & 0.83 & 0.83 & 0.56 & 0.90 & 0.90 & 0.46 & 0.75 & 0.75 \\
\hline Lavras & 0.85 & 0.87 & 0.88 & 0.85 & 0.93 & 0.93 & 0.73 & 0.81 & 0.82 \\
\hline Machado & 0.89 & 0.89 & 0.90 & 0.75 & 0.94 & 0.94 & 0.67 & 0.84 & 0.85 \\
\hline Mocambinho & 0.81 & 0.74 & 0.84 & 0.80 & 0.84 & 0.91 & 0.65 & 0.62 & 0.77 \\
\hline Monte Azul & 0.63 & 0.64 & 0.67 & 0.77 & 0.78 & 0.80 & 0.48 & 0.49 & 0.54 \\
\hline Montes Claros & 0.83 & 0.84 & 0.85 & 0.86 & 0.91 & 0.92 & 0.71 & 0.76 & 0.78 \\
\hline P. de Caldas & 0.86 & 0.87 & 0.87 & 0.74 & 0.93 & 0.93 & 0.64 & 0.80 & 0.81 \\
\hline Patos de Minas & 0.76 & 0.80 & 0.80 & 0.80 & 0.88 & 0.89 & 0.61 & 0.70 & 0.71 \\
\hline Paracatu & 0.80 & 0.81 & 0.82 & 0.85 & 0.89 & 0.90 & 0.68 & 0.72 & 0.73 \\
\hline Paranaíba & 0.86 & 0.86 & 0.87 & 0.81 & 0.92 & 0.93 & 0.69 & 0.80 & 0.81 \\
\hline Pedra Azul & 0.85 & 0.86 & 0.86 & 0.86 & 0.92 & 0.93 & 0.73 & 0.79 & 0.80 \\
\hline Pirapora & 0.83 & 0.83 & 0.85 & 0.82 & 0.90 & 0.91 & 0.68 & 0.75 & 0.78 \\
\hline Pompéu & 0.84 & 0.85 & 0.86 & 0.75 & 0.92 & 0.92 & 0.63 & 0.78 & 0.79 \\
\hline Salinas & 0.86 & 0.87 & 0.87 & 0.82 & 0.93 & 0.93 & 0.70 & 0.81 & 0.81 \\
\hline São Lourenço & 0.92 & 0.92 & 0.92 & 0.78 & 0.96 & 0.96 & 0.72 & 0.88 & 0.89 \\
\hline São Mateus & 0.75 & 0.76 & 0.77 & 0.78 & 0.87 & 0.87 & 0.59 & 0.66 & 0.68 \\
\hline São S. do Paraíso & 0.84 & 0.84 & 0.85 & 0.77 & 0.91 & 0.92 & 0.65 & 0.77 & 0.78 \\
\hline Sete Lagoas & 0.84 & 0.85 & 0.86 & 0.82 & 0.91 & 0.92 & 0.69 & 0.77 & 0.80 \\
\hline Uberaba & 0.78 & 0.80 & 0.81 & 0.81 & 0.89 & 0.89 & 0.63 & 0.71 & 0.72 \\
\hline Unaí & 0.78 & 0.80 & 0.82 & 0.71 & 0.89 & 0.90 & 0.56 & 0.71 & 0.73 \\
\hline Viçosa & 0.90 & 0.90 & 0.90 & 0.82 & 0.95 & 0.95 & 0.74 & 0.85 & 0.85 \\
\hline Vitória & 0.80 & 0.81 & 0.82 & 0.87 & 0.90 & 0.90 & 0.70 & 0.73 & 0.74 \\
\hline
\end{tabular}


Borges Júnior et al. (2017), evaluating the HS and HS method calibrated at different time scales for the city of Sete Lagoas-MG, verified that after calibration there were high concentrations of deviations between -1 and $1 \mathrm{~mm}$ referring to the standard method, being $64.0 \%, 90.8 \%, 91.1 \%, 91.4 \%$ and $91.7 \%$, respectively, for the original HS method and with annual, semester, quarterly and monthly calibration. In the present study, intervals of deviations between -1 and 1 $\mathrm{mm}$ from 3.35\% (Lambari-MG) to 87.82\% (Paracatu-MG) were found for the HS method, $75.68 \%$ (Espinosa-MG) and 99.99\% (Bambuí-MG) for the HScal method and 79.11\% (Vitória-ES) and 99.99\% (Bambuí-MG) for the MP.

\section{CONCLUSIONS}

It was found that the calibration of the HS method provided a significant improvement in 50 of 52 of the studied stations when compared to the standard FAOPM method. In relation to MP, a similar performance to that observed for the HScal method was observed for all the stations studied, with a slight decrease in the MAE and RMSE values and a slight increase for the Pearson correlation coefficient (r) and agreement index of Willmott (d), when compared with the HScal method. The HScal and MP methods are appropriate alternatives for estimation of $\mathrm{ET}_{0}$ in all climatic regions of Minas Gerais State, particularly for the very remote stations having only minimum and maximum temperature records.

\section{ACKNOWLEDGEMENTS}

The authors express their gratitude to FAPEMIG for the support and funding for research development, and Brazilian National Institute of Meteorology (INMET) for making the series of meteorological data available.

\section{REFERENCES}

ALLEN, R. G. et al. Crop evapotranspiration: Guidelines for computing crop requirements. Rome: FAO Irrigation and Drainage Paper 56, 1998. 300p.

AGÊNCIA NACIONAL DE ÁGUAS - ANA. Atlas irrigação: Uso da água na Agricultura Irrigada/Agência Nacional de Águas. Brasília: ANA, 2017. 86p.

ARRAES, F. D. D. et al. Parametrização da equação de HargreavesSamani para o estado do Pernambuco-Brasil. Revista Brasileira de Agricultura Irrigada, 10(1):410-419, 2016.

BERTI, A. et al. Assessing reference evapotranspiration by the Hargreaves method in north eastern Italy. Agricultural Water Management, 140(1):20-25, 2014.
BOGAWSKI, P.; BEDNORZ, E. Comparison and validation of selected evapotranspiration models for conditions in Poland (Central Europe). Water Resources Management, 28(14): 5021-5038, 2014.

BORGES JÚNIOR, J. C. F. et al. Equação de Hargreaves-Samani calibrada em diferentes bases temporais para Sete Lagoas, MG. Revista Engenharia na Agricultura, 25(1):38-49, 2017.

BORGES JÚNIOR, J. C. F. et al. Computational modeling for irrigated agriculture planning. Part I: General description and linear programming. Engenharia Agrícola, 28(3):471482. 2008b.

BORGES JÚNIOR, J. C. F. et al. Computational modeling for irrigated agriculture planning. Part II: Risk analysis. Engenharia Agrícola, 28(3):483-493. 2008a.

DJAMAN, K. et al. Evaluation of sixteen reference evapotranspiration methods under sahelian conditions in the Senegal River Valley. Journal of Hydrology: Regional Studies, 3(1):139-159, 2015.

DROOGERS, P.; ALLEN, R. G. Estimating reference evapotranspiration under inaccurate data conditions. Irrigation and Drainage Systems,16(1):33-45, 2002.

FENG, Y. et al. Calibration of Hargreaves model for reference evapotranspiration estimation in Sichuan basin of southwest China. Agricultural Water Management, 181(1):1-9, 2017.

FERREIRA, L. B. et al. Calibration methods for the HargreavesSamani equation. Ciência e Agrotecnologia, 42(1):104$114,2018$.

HARGREAVES, G. H.; SAMANI, Z. A. Reference crop evapotranspiration from ambient air temperature. American Society of Agricultural Engeneering, 1(2):96-99, 1985.

MAESTRE-VALERO, J. F.; MARTÍNEZ-ÁLVAREZ, V.; GONZÁLEZREAL, M. M. Regionalization of the Hargreaves coefficient to estimate long-term reference evapotranspiration series in SE Spain. Spanish Journal of Agricultural Research, 11(4):1137-1152, 2013.

MALLIKARJUNA, P. et al. Performance of recalibrated equations for the estimation of daily reference evapotranspiration. Water Resources Management, 28(13):4513-4535, 2014.

MARTÍ, P. et al. Modeling reference evapotranspiration with calculated targets. Assessment and implications. Agricultural Water Management,149(1):81-90, 2015a.

MARTÍ, P. et al. Parametric expressions for the adjusted Hargreaves coefficient in Eastern Spain. Journal of Hydrology, 529(1):1713-1724, $2015 b$. 
MELO, G. L. de; FERNANDES, A. L. T. Evaluation of empirical methods to estimate reference evapotranspiration in Uberaba, State of Minas Gerais, Brazil. Engenharia Agrícola, 32(5):875-888, 2012.

PANDEY, V.; PANDEY, P.K.; MAHANTA, A. P. Calibration and performance verification of Hargreaves Samani Equation in a Humid Region. Irrigation and Drainage, 63(5):659667, 2014.

PAREDES, P. et al. Daily reference crop evapotranspiration in the humid environments of Azores islands using reduced data sets: Accuracy of FAO-PM temperature and Hargreaves-Samani methods. Theoretical and Applied Climatology, 134(1-2):595-611, 2017.

PEREIRA, L. S. et al. Crop evapotranspiration estimation with FAO56: Past and future. Agricultural Water Management, 147(1):4-20, 2015.

SHIRI, J. et al. Comparison of heuristic and empirical approaches for estimating reference evapotranspiration from limited inputs in Iran. Computers and Electronics in Agriculture, 108(1):230-241, 2014.

SHIRI, J. et al. Independent testing for assessing the calibration of the Hargreaves-Samani equation: New heuristic alternatives for Iran. Computers and Electronics in Agriculture, 117(1):70-80, 2015.
SILVA, A. O. da et al. Avaliação de desempenho de métodos de estimativa de evapotranspiração potencial para a região norte de Recife - PE. Engenharia na Agricultura, 20(2):163-174, 2012.

STEIDLE NETO, A. J. et al. Reference evapotranspiration estimates based on minimum meteorological variable requirements of historical weather data. Chilean journal of Agricultural Research, 75(3):366-374, 2015.

VALIANTZAS, J. D. Simplified reference evapotranspiration formula using an empirical impact factor for Penman's aerodynamic term. Journal of Hydrologic Engineering, 18(1):108-114, 2013.

VALIPOUR, M. Temperature analysis of reference evapotranspiration models. Meteorological Applications, 22(3):385-394, 2015.

WILLMOTT, C. J.; MATSUURA, K. Advantages of the mean absolute error (MAE) over the root mean square error (RMSE) in assessing average model performance. Climate Research, 30(1):79-82, 2005.

WILLMOTT, C. J.; ROBESON, S. M.; MATSUURA, K. A refined index of model performance. International Journal of Climatology, 32(13):2088-2094, 2012.

ZHAO, S. et al. Rapid evaluation of reference evapotranspiration in Northern China. Arabian Journal of Geosciences, 8(2):647-657, 2015. 